Discussion Paper No. 15-026

\title{
Politicians' Promotion Incentives and Bank Risk Exposure in China
}

Li Wang, Lukas Menkhoff, Michael Schröder, and Xian Xu

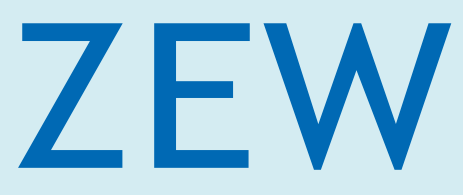

Zentrum für Europäische Wirtschaftsforschung $\mathrm{GmbH}$

Centre for European

Economic Research 
Discussion Paper No. 15-026

\title{
Politicians' Promotion Incentives and Bank Risk Exposure in China
}

\author{
Li Wang, Lukas Menkhoff, Michael Schröder, \\ and Xian Xu
}

Download this ZEW Discussion Paper from our ftp server:

http://ftp.zew.de/pub/zew-docs/dp/dp15026.pdf

Die Discussion Papers dienen einer möglichst schnellen Verbreitung von neueren Forschungsarbeiten des ZEW. Die Beiträge liegen in alleiniger Verantwortung der Autoren und stellen nicht notwendigerweise die Meinung des ZEW dar.

Discussion Papers are intended to make results of ZEW research promptly available to other economists in order to encourage discussion and suggestions for revisions. The authors are solely responsible for the contents which do not necessarily represent the opinion of the ZEW. 


\title{
Politicians’ Promotion Incentives and Bank Risk Exposure in China
}

\author{
Li Wang ${ }^{\mathrm{a}}$ \\ Lukas Menkhoff ${ }^{b}$ \\ Michael Schröder ${ }^{c}$ \\ $\mathrm{Xian} \mathrm{Xu}^{\mathrm{a}}$
}

\begin{abstract}
This paper shows that politicians' pressure to climb the career ladder increases bank risk exposure in their region. Chinese local politicians are set growth targets in their region that are relative to each other. Growth is stimulated by debt-financed programs which are mainly financed via bank loans. The stronger the performance incentive the riskier the respective local bank exposure becomes. This effect holds primarily for local banks which are under a certain degree of control of local politicians and it has increased with the release of recent stimulus packages requiring local co-financing.
\end{abstract}

JEL-Classification: G21; G23; H74

Keywords: $\quad$ Bank Lending; Bank Risk Exposure; Local Politicians; Promotion Incentives

April, 2015

${ }^{\text {a }}$ Fudan University, Shanghai, China

${ }^{\mathrm{b}}$ DIW Berlin, and Humboldt University, Berlin, Germany

${ }^{\mathrm{c}}$ Zentrum für Europäische Wirtschaftsforschung (ZEW), Mannheim, and Frankfurt School of Finance \& Management, Frankfurt/Main, Germany. Email: schroeder@zew.de 


\section{Politicians’ Promotion Incentives and Bank Risk Exposure in China}

\section{Introduction}

Government involvement in the banking sector is often met with skepticism. Scholars, such as Krueger (1974) or Shleifer et al. (1994), argue that politicians' personal objectives distort the bank’s performance and lead to a misallocation of resources. Distortions arise from either misusing banks for politicians' direct private benefit or indirectly supporting their career by means of political credit cycles (Sapienza, 2004; Dinc, 2005; Micco et al., 2007). Typically, empirical studies identify politically driven distortions by comparing banks under political influence to banks that are run fully privately (Iannotta et al., 2012; Pereira and Maia-Filho, 2013). To some extent, this approach is always infected by non-political factors which also give rise to different behavior between bank types. For example, banks under public supervision often pursue different objectives targets than private banks and thus the two groups of banks may be not fully comparable to each other.

Therefore, in our research on the impact of government involvement we follow an approach which is not based on comparing bank types. Instead we measure scope and scale of politicians' incentives which is meaningful because the promotion system is fully centralized within China (Jin et al., 2005). Promotion mainly follows the achievements realized by local politicians that are largely defined by quantifiable measures (Li and Zhou, 2005; Xu, 2011). Whether such a promotion policy is adequate in various respects has been questioned in Chinese studies, especially in the attempt of shedding light on negative effects on the performance of banks in China (e.g., Qian et al., 2011). These negative effects arise from the strong incentives set for politicians to stimulate economic growth in combination with their limited liability.

The main economic problem of these distorted incentives is not only the quality of lending but also the sheer amount of local debt. The rapidly rising debt of Chinese local governments, i.e. all levels of government below the central government, has led to major concerns. ${ }^{1}$ Owing to inadequate repayment capabilities, some local governments are left with

\footnotetext{
${ }^{1}$ In fact, the Chinese political hierarchy has five administrative layers: the central government, provinces, prefectures, counties and townships ( $\mathrm{Li}$ and Zhou, 2005; Jin et al., 2005; Xu, 2011). Local governments
} 
only two: either repaying old debts by raising new ones or not paying off debts that are overdue. The latter has been recently observed in some localities. ${ }^{2}$ Worse still, according to an audit report by the National Audit Office in 2013, 78.1\% of the debt comes from banks, ${ }^{3}$ showing that local governments are closely related to the banking system. It seems that no one is able to understand in depth the risk of Chinese banks without considering the role of local governments.

Our approach rests on detailed data about balance sheet information of banks in China, allowing us to calculate indicators of risk taking, including necessary control variables. Banks' risk taking is explained by a set of standard variables which are complemented by our variable of interest, i.e. an index of political pressure to perform. Based on data for the period 2005 to 2012 we find that such a pressure index explains risk taking of banks in the respective region. The result also holds in IV-regressions. This finding provides a novel identification of political influence on the banking system, which is of interest for researchers but also adds to the applied policy discussion in China.

This main result is corroborated by two more findings: first, the impact from political pressure is only relevant for banks that operate regionally, possibly because they cannot avoid the pressure. Second, we find that the relation between political pressure and risk taking has become stronger and more significant after the financial crisis. The crisis brought large-scale macroeconomic stimuli to the Chinese economy which required the local politicians to co-finance certain projects.

Moreover, we reveal the channels by which risk taking takes place, i.e. by reducing liquidity, increasing loan volume and reducing loan quality. Finally, further robustness checks regarding definition of variables and methods support our main findings.

Our paper is close in spirit to the "political view" of government involvement in the banking system which emphasizes the inefficient outcomes resulting from politicians' deliberate policy of maximizing their own personal objectives (Krueger, 1974; Shleifer and

(subnational governments or lower-tier governments) refer to any layer from the last four administrative layers. In the empirical part of this paper, we mainly focus on local governments at provincial and prefecture level. The term "local politicians" refers to local government officials.

2 Source: The Audit Report by National Audit Office of the People's Republic of China (No.24 of 2013, http:/ /www.audit.gov.cn/n1992130/n1992150/n1992500/3291665.html).

${ }^{3}$ Source: The Audit Report by National Audit Office of the People's Republic of China (No.24 of 2013, http:/ /www.audit.gov.cn/n1992130/n1992150/n1992500/3291665.html). 
Vishny, 1994). As argued by Hainz and Hakenes (2012), a selfish politician often uses subsidized banks inefficiently from a welfare perspective. However, we focus on bank risk and not on overall bank performance (La Porta et al., 2002; Qian et al., 2011) or general bank lending behavior (Sapienza, 2004; Becker, 2007). ${ }^{4}$ Moreover, we explicitly show the impact of politicians' promotion incentives and thus specify more general political considerations which have long been claimed as the main cause of distorted allocation of financial resources (Imai, 2012; Gur, 2012). Then, this paper stresses the role of subnational government officials, i.e. local politicians, in bank risk exposure. Unlike the traditional "political view" which relies on the election system of federal states (Sapienza, 2004; Dinc, 2005; Micco et al., 2007), we explore a more specific Chinese style risk-channeling mechanism.

Different from the studies which emphasize the positive role of Chinese politicians' promotion incentives in pushing forward economic development and reducing inequality between regions (Jin et al., 2005; Li and Zhou, 2005), our paper highlight the visible cost brought about by this promotion policy, such as inefficient investment and financing model going along with increasing bank risk.

The remainder of the paper is organized as follows. Section 2 provides some stylized facts about China's political promotion system, followed by a detailed analysis of the risk channeling mechanisms. Section 3 describes our data, sample and econometric methodology. Section 4 presents results of our empirical analysis. Section 5 gives further results as well as robustness checks. Section 6 concludes.

\section{Stylized Facts and Mechanism in China: Local Politicians and Bank Risk Exposure}

\subsection{Institutional Background}

Different from other transitional and developing countries, both the high degree of political centralization and fiscal decentralization in China make political promotion an important incentive for yardstick competition among local government officials (Blanchard and Shleifer, 2000; Jin et al., 2005). The central government, under the tight control of the

\footnotetext{
${ }^{4}$ Different from Hakenes and Schnabel (2014) who focus on the bailout policy of government and Qian et al. (2015) who focus on the incentives of bank loan officers, our paper emphasizes the role of local politicians. As argued by Hakenes and Schnabel (2014), bailout expectation leads to steeper bonus schemes and even more risk taking if there is a risk-shifting problem. Qian et al. (2015) point out that higher incentives of loan officers to produce high-quality information after the reforms of Chinese banks between 2002 and 2003 can help forecast future loan performance.
} 
Chinese Communist Party (CCP), has the ultimate authority to decide on the appointment and removal of all the lower-tier government officials (i.e. local politicians) through a nested personnel-control network (Xu, 2011). Meanwhile, local governments are empowered to allocate economic resources in their regions (devolution of government authority) and are responsible for their economic performance. This centrally controlled decentralization not only links the political promotion of local officials to the economic development goals of the central government, but also enables local governments to independently make resource allocation arrangements in their own regions. Relative performance evaluations are widespread in China: provinces, cities, counties, townships and villages are continually ranked by their performance in growth, output and foreign investment (Maskin et al., 2000). Anyone who has been ranked towards the top in these evaluations or has been awarded the title of “advanced leader”, is more likely to be promoted as a “political bonus” (Xu, 2011).

Though this economic performance-based promotion system has motivated local politicians to lend a "helping hand" in pushing forward local economic growth and reducing inequality between regions (Jin et al., 2005; Li and Zhou, 2005), it also brings about many problems due to the fierce competition in public investment and financial resource grabbing of local governments. Large quantity-based performance indicators, such as GDP growth, building of infrastructure and foreign investment attraction, not only encourage "image projects”, “achievement projects” and “redundant projects”, but also place a large burden on local financing. Sichuan Province, one of the commonly-seen localities ambitious invest in infrastructure projects, ${ }^{5}$ has just announced its new plans of spending 4.3 trillion yuan only on the construction of three highways, five railroads and one airport over the next two years. The figure doubles Sichuan's GDP of the entire year 2012 and is 10 times as high as its fiscal revenue during the same period. ${ }^{6}$ How can local governments raise all the money they need for their ambitious investments? Ever since 1994, Chinese local governments are not allowed to borrow money directly or run a budget deficit. Large funding gaps resulting from yardstick competition of local government officials stimulate the innovation of less-regulated and

\footnotetext{
${ }^{5}$ More description about fierce competition of local governments in public investment and financial resource grabbing can be seen in Li and Zhou (2005) etc.

${ }^{6}$ Source: China's Local Government Debt Crisis: Though Heavily Leveraged and Linked to Shadow Banks, Provincial Infrastructure Spending Will Come Just Short of A Hard Landing (International Business Times, 2013).
} 
riskier debt-financing vehicles. Table B1 in Appendix B gives a time table of major events related to Chinese local debts since 2008.

Financing platforms, one of the vehicles which have evolved in China, provide local governments with a corporate structure ${ }^{7}$ to borrow from the market (85\% are bank loans) and to quickly develop infrastructure. They are treated as municipal corporations under the Company Law of the Peoples' Republic of China (PRC). However, the law does not clarify the relationship between financing platforms and the local government, including the limits of the financial liability of the local governments. The platforms act as financing units, public sector investor, land development agent and project sponsor (or owner). An estimated 70\% of financing platforms are under the direct control of the municipal governments, while in other cases they may report to the department of construction, the local asset management department, or the local department of reform and development (World Bank, 2009). Table 1 describes the debt raising units of local governments by the end of 2012. Financing platform companies account for $45.7 \%$ of the total audited local government debts, underpinning its significant role in bank risk channeling.

\subsection{Mechanisms and Hypotheses}

Though the concept of a "promotion-motivated competition model" and its impact on local public investment and economic growth have gained much academic consensus nowadays in China, it is still only a few researchers who consider the impact this model may have on the stability of China's financial system. Researchers like Qian et al. (2011) or Li and Qian (2012) pay attention to the credit effect of this "promotion-motivated competition model". Their work shows that the promotion of local politicians has a significant effect on the quantity of credit by local commercial banks. Higher promotion incentive is usually associated with more credit of medium and long term (Qian et al., 2011). However, the risk of banks, in the process of financial resource grabbing, has been under-researched until now. As shown in Table 1, almost $80 \%$ of government debts come from bank loans, indicating that the usage of bank money and its financing models will inevitably impact bank risk. Figure 1

\footnotetext{
${ }^{7}$ This is a notation that appears in a World Bank's report related to Chinese Financing Platforms (See World Bank, 2009). The notation may well capture two aspects of financing platforms: First, from the view of the Company Law of the Peoples' Republic of China (PRC), these platforms embody corporation characteristics. Second, from the view of the relationship between these platforms and local governments, they act as agents of local governments, raising funds and sponsoring infrastructure construction etc.
} 
summarizes several mechanisms how political promotion incentives may affect bank risk.

First, since $92.1 \%$ of local government debts are spent on public infrastructure projects whose recovery of funds takes a fairly long time, banks are likely to suffer a higher credit and default risk due to the longer loan term and lower bank liquidity (see Campbell and Taksler, 2003 for the relationship between term and risk). Potential payment risk confronted by banks is also likely to be driven up due to the accumulation of loans invested in low-yield infrastructure projects. According to an audit report announced by the National Audit Office of China in 2011, a total of 1,734 (i.e. 26.4\%) platforms were loss-making companies by the end of 2010. Massive debts used for building expressways, universities of higher education and hospitals has put some localities under heavy pressure to repay debts because of the low fee collections. ${ }^{8}$

Second, the quality of bank loans can deteriorate as a result of financing platforms experiencing severe problems such as "land finance" (dudi caizheng), bad asset quality, and imperfect guarantee mechanisms. The repayment of debts depends heavily on the revenue of land sales, which may account for more than half of the total promised debt repayment in some localities. However, with the implementation of a series of stringent real estate policies and a slowdown of the Chinese economy in recent years, land revenue can no longer meet the promised volume target as easily as before. Moreover, it is also evident that some financing platform companies strive to obtain debt funds by using fake or illegal quality-based mortgages or overestimate the values of quality-based mortgages. ${ }^{9}$ Finally, a reciprocal guarantee model of the platforms makes it more likely for a platform to be affected by contagion effects.

Third, the shorter average tenure of local politicians caused by promotion competition and career mobility strengthens the tendency for local governments to over-issue debts, leading to an increase in bank risk. Frequent turnover of government officials encourages the prevalence of short-term opportunism (Persson and Tabellini, 2000). Thus, if politicians can expect the current debt burden to be transferred to their successors after a successful political promotion,

\footnotetext{
${ }^{8}$ Source: The Audit Report by National Audit Office of the People’s Republic of China (No.35 of 2011, http://www.audit.gov.cn/n1992130/n1992150/n1992500/2752208.html).

${ }^{9}$ Reference: The Audit Report by National Audit Office of the People's Republic of China (No.35 of 2011, http://www.audit.gov.cn/n1992130/n1992150/n1992500/2752208.html).
} 
they will tend to be more careless about investing and debt-financing (Persson and Svensson, 1989; Alesina and Tabellini, 1990).

Given the above discussed sources of bank risk, this paper hypothesizes that:

Hypothesis 1. Promotion incentives of local politicians may affect bank risk, and an increase in promotion incentives will lead to an increase in bank risk.

One may argue that the effect of promotion incentives on bank risk can differ among different banks. According to an official report, platforms of prefecture-level and county-level account for $70 \%$ of the total number of platforms in China ${ }^{10}$, implying that city commercial banks and rural cooperative financial institutions are more vulnerable to the crash of platforms. Besides, direct bank control or personnel appointment rights in some prefectures and counties facilitate yardstick competition. Some city commercial banks are even regarded as the "second finance level” of local governments (Qian et al., 2011). Thus, it is more likely for banks on prefecture-level and county-level to be affected by local politicians' promotion incentives. We therefore also propose that:

Hypothesis 2. The effect of promotion incentives on bank risk is more significant for city commercial banks and rural cooperative financial institutions.

We consider the possibility that the effect of promotion incentives on bank risk may differ over time. To mitigate the shocks brought about by the global financial crisis of 2008, the Chinese central government announced the implementation of a 4 trillion yuan stimulus package aimed at the development of indemnificatory housing projects, rural construction, communication and transportation construction etc. The policy support for expanding infrastructure did not only intensify the fierce public investment competition among local governments, but also imposed a heavy financial burden on local governments as it was required that $70 \%$ of the funds needed by the package were to be reallocated from the budget of local governments. According to the Chinese Regional Financial Operation Report (2010) released by the central bank, the total number of platform companies which played a significant role in grabbing financial resources from banks for local governments exceeded

\footnotetext{
10 Source: The Audit Report by National Audit Office of the People’s Republic of China (No.35 of 2011, http://www.audit.gov.cn/n1992130/n1992150/n1992500/2752208.html).

11 Source: The Chinese Regional Financial Operation Report(2010, http://www.pbc.gov.cn/publish/goutongjiaoliu/ 524/2011/20110601212610189374552/20110601212610189374552_.html).
} 
10,000 by the end of 2010 , while there were only around 3,000 at the first half of 2008 . This rapid increase may indicate a more significant relationship between promotion incentives and bank risk. Furthermore, many local politicians tend to be more enthusiastic about better economic indexes and ranking results during crises to prove their ability of dealing with crises. Therefore we expect that:

Hypothesis 3. The effect of promotion incentives on bank risk is more significant after the global crisis of 2008 .

\section{Data and Empirical Strategy}

\subsection{Data}

Since a balanced panel would reduce our sample considerably, we test the hypothesis using an unbalanced panel of 147 Chinese banks for the period 2005-2012. All the banks in the sample have observations of at least 4 years, so that we still cover nearly $80 \%$ of the total of Chinese banks with publicly-released data. ${ }^{12}$ Our empirical results are robust to including banks with less than 4-year observations or using the balanced panel extracted from the current sample. ${ }^{13}$ Accounting data on banks stem from the annual reports of each bank, and data on the macro-economy are all sourced from the "China City Statistical Yearbook", the “China Statistical Yearbook” or the website of the People’s Bank of China.

Regarding bank specialization, we distinguish four major kinds of Chinese banks in our sample, i.e. large commercial banks, joint-stock commercial banks, city commercial banks and rural cooperative financial institutions. As shown in Table 2, all the existing five large commercial banks (i.e. Industrial and Commercial Bank of China, Agricultural Bank of China, Bank of China, China Construction Bank and Bank of Communications) and 12 joint-stock commercial banks (i.e. China Citic Bank, China Everbright Bank, Huaxia Bank, China Guangfa Bank, Ping An Bank, China Merchants Bank etc.) in China are included in our data set. These two kinds of banks account for $11.6 \%$ of the total number of banks and they are referred to as national commercial banks. Local commercial banks, like city commercial banks (63.9\% of the total number of banks), rural commercial banks and rural cooperative financial institutions (24.5\% of the total number of banks), constitute the most important part

\footnotetext{
12 The percentage is based on the number of banks established before 2010.

${ }^{13}$ We do not report full regression results in this part since there is a large number of regressions citation with qualitatively similar results.
} 
of our sample.

\subsection{Empirical Strategy}

\subsubsection{Empirical Model}

Our first and main hypothesis is that promotion incentives of local politicians can affect bank risk taking, and an increase in promotion incentives will lead to an increase in bank risk. The basic empirical specification to test the hypothesis is given as follows,

$$
Z_{b, t}=\alpha_{0}+\alpha_{1} P_{b, t-1}+\alpha_{2} X_{b, t-1}+\alpha_{3} Y_{t-1}+\alpha_{4} M_{t-1}+\mu_{b, t}
$$

where $Z_{b, t}$ is a measure of the risk of bank $b$ for period t. $P_{b, t-1}$ are the promotion incentives of local politicians corresponding to bank $b . X_{b, t-1}$ is a matrix of bank-level control variables, $Y_{t-1}$ represents macro-level control variables, $M_{t-1}$ controls for the impact of the concentration in the banking sector. $\mu_{b, t}$ is the error term and $\alpha_{1}, \alpha_{2}, \alpha_{3}$, $\alpha_{4}$ are slope coefficients or vectors of coefficient estimates. According to Hypothesis 1 , $P_{b, t-1}$ is the key variable in the regression, and we expect the corresponding coefficient $\alpha_{1}$ to be negative. The construction and measure of all variables is described in detail in Section 3.2.3.

It is possible that our results are affected by the endogeneity of political promotion: The risky behavior of banks may impact a series of macro-economic variables, leading to a change in the promotion incentive of local politicians. ${ }^{14}$ To alleviate this problem, all the explanatory variables are lagged by one period (see Marques et al., 2013). In addition to that procedure, an instrumental variable approach will also be introduced in the next section.

\subsubsection{Instrumental Variable Approach}

We propose fiscal decentralization as an instrumental variable for the political promotion index. The argument runs that higher fiscal decentralization gives local politicians more rights to make resource allocation decisions in their own regions (Zhou, 2007), which more likely lead to better economic ranking and lower promotion pressure. At the same time, there is no obvious direct relation between the degree of fiscal decentralization and bank risk taking.

\footnotetext{
${ }^{14}$ In the variable construction part, we will show how promotion incentive is related to macro-economic variables under an economic performance-based promotion system.
} 
As a measure of fiscal decentralization, we primarily use the ratio of local government's own revenue to its total expenditure (Akai and Sakata, 2002). Compared with two other commonly used proxies for fiscal decentralization, the share of local government's spending in total government spending (Qiao et al., 2008) and the share of local government's overall revenue in total government revenue (Wang, 2013), our measure can well reflect how public spending at lower-level government is maintained on the basis of its own revenue (Ebel and Yilmaz, 2002). Actually, our results still hold when we use the share of local government's spending (revenue) in total government spending (revenue) as the instrumental variable for fiscal decentralization.

To show the appropriateness of fiscal decentralization as an instrument of political promotion in an econometric sense, we also conduct two tests. First, we confirm that there is an econometric endogeneity problem by the Hausman specification test. The significant difference in the coefficients between Instrumental regression and the regression without an IV (with p-value 0.000) indicates that there exists an econometric endogenous variable in our basic regression, supporting the necessity for our instrumental variable approach. In the second test, we check if fiscal decentralization enters the first-stage regression significantly through the F-test of excluded instruments. A reported p-value of 0.000 shows us a significant correlation between fiscal decentralization and promotion incentive. Thus, in this case we do not need to be concerned about a weak instrument problem of the fiscal decentralization.

From the view of both economic and econometric aspects, it seems therefore appropriate to use fiscal decentralization as an instrument variable for political promotion pressure.

\subsubsection{Construction of the Variables}

In this section we explain the construction of variables which we use in the above introduced regressions. The LHS variable is bank risk Z, the RHS variables are promotion incentives $\mathrm{P}$, bank-level controls $\mathrm{X}$, macro-level controls $\mathrm{Y}$, bank concentration $\mathrm{M}$ and for later analyses (in Section 5.1) channel-specific variables B.

(a) Bank risk variable $Z_{b, t}$ : Existing literature has shown a variety of measures for risk, such as expected default frequency (Altunbas et al., 2010), risk asset ratio (Gropp et al., 2011) or, volatility of equity returns (Laeven and Levine, 2009), in order to capture different aspects 
of bank risk. Because of the shortage of default and equity return data (Zhang and He, 2012), expected default frequency and volatility of equity returns are not appropriate measures to capture the risk of most banks especially when looking at the local banks in China. Besides, some banks don't directly report risk asset volume or risk asset ratio. Thus, in this paper, we primarily use the z-score (Laeven and Levine, 2009; Beck et al., 2013; Distinguin et al., 2013), which equals the return on assets plus the capital asset ratio of each bank divided by the standard deviation of asset returns, to measure bank risk. As a broader measure of risk, it encompasses both credit risk and market risk (Marques et al., 2013), and it is also widely used in empirical research of the Chinese banking sector. ${ }^{15}$ A higher z-score indicates a less risky bank. We compute the standard deviation of asset returns using 4-year rolling windows (Distinguin et al., 2013) and take the natural logarithm of it because of the high skewness (Laeven and Levine, 2009). Alternative periods of rolling windows ${ }^{16}$ and risk measures will be applied for the robustness check.

(b) Promotion incentives $P_{b, t}$ : Since local politicians who are under higher pressure to climb the political career ladder tend to have more incentives to be ranked higher in the relative performance evaluation, we construct a 'promotion pressure index' to measure the promotion incentives of local politicians. Based on the method of Qian et al. (2011), we first calculate the promotion pressure index $P_{i, t}$ for local politicians in each administrative region (denoted by $i$ ), including 31 province-level regions ${ }^{17}$ and 283 prefecture-level cities in China. ${ }^{18}$ The promotion incentives $P_{b, t}$, for local commercial banks then correspond to the promotion pressure index of the regions where these banks operate $\mathrm{in}^{19}$, for national commercial banks they correspond to the weighted average level of the promotion pressure index (weighted by the number of subsidiaries in each province).

\footnotetext{
15 See the work of Xu and Chen (2012).

${ }^{16}$ See Beck et al. (2013), Distinguin et al. (2013) for a 3-year rolling window application and see Laeven and Levine (2009), Marques et al. (2013) for a 5-year rolling window application.

${ }_{17}$ Cities like Beijing, Shanghai, Chongqing and Tianjin are province-level regions. Moreover, we exclude Hongkong and Macao here since their political systems (they are allowed to adhere to the capitalist system) are different from the mainland's system and they also have a high degree of autonomy in legislation and final jurisdiction etc.

${ }^{18}$ It is really a Chinese-specific index, since the appointment and removal of local politicians depend considerably on the relative performance of politicians. Section 3.1 can also help us to understand the reason why we construct the promotion index in the way we do. We differ from other researchers such as Qian et al. (2011) whose pressure score has only two values (better than the average level: 0 ; worse than the average level: 1 ), by dividing the values of each indicator into more intervals. Thus our index can better reflect the relative situations.

19 Some city commercial banks such as Jiangsu Bank, Huishang Bank and Jilin Bank have been restructured to be provincial banks, thus correspond to the pressure index of related provinces.
} 
The construction of promotion pressure index $P_{i, t}$ is shown as follows. First of all, we need to choose evaluation indicators that are essential for politicians' promotion. As Xu (2011) pointed out, multiple tasks of a regional government can be effectively converted into a single task, achieving a high GDP growth rate. Therefore, we include GDP growth rate as the most important evaluation indicator for our index construction. In addition, fiscal surplus and unemployment have also shown to be significant in the evaluation of local development in recent years (Qian et al., 2011), thus we will consider these two indicators as well. The promotion incentive variable in our paper in fact reflects the promotion pressure on local politicians exerted by GDP growth rate, fiscal surplus and employment rate. ${ }^{20}$ The next step is to construct pressure score $S_{i, t}^{k}$ for region $i$ based on the relative performance in each indicator $k$ within the same administrative level, as the appointment and removal of local politicians depend considerably on the relative performance of politicians from the same administrative level. For prefecture-level cities, a comparison will be made among the cities in the same province rather than among all cities all over the country, since province-level leaders have the power to hire and fire staff in prefecture-level cities (Xu, 2011). Yardstick competition is also more likely to happen among prefecture-level cities of the same province. Thus, one gets the promotion pressure index $P_{i, t}$ by summarizing $S_{i, t}^{k}$ according to indicator $k$, namely $P_{i, t}=\sum_{k} S_{i, t}^{k}$. More detailed information about the construction of promotion incentives $P_{b, t}$ is provided in Appendix A.

(c) Bank-level control variables $X_{b, t-1}$ : Based on the work of Laeven and Levine (2009) and Altunbas et al. (2010), we include bank size, ownership structure and capital to asset ratio as bank-specific control variables. Bank size is measured as the log of banks' total assets. The ownership structure is measured by two dummy variables which take the value of one or zero respectively if the bank is state-owned or state-legal-person owned. Capital to asset ratio is the inverse of the leverage of banks. Theory suggests that large and well-capitalized banks are better placed to buffer their lending activity against shocks affecting the availability of external finance (Gambacorta and Mistrulli, 2004; Altunbas et al., 2010). However, as Boyd

\footnotetext{
${ }^{20}$ We define fiscal surplus here as the fiscal revenue minus the fiscal expenditure divided by GDP. More economic performance indicators such as FDI, transportation and road construction are considered in the robustness check.
} 
and Runkle (1993) and Cukierman (2011) pointed out, "too big to fail” perceptions may encourage large banks to take more risks. Higher capital may also induce higher bank risk as a result of less monitoring efforts (Dell' Ariccia et al., 2010). Thus, there is no consistent relationship between bank size (or capital to asset ratio) and bank risk. We also include banks' ownership structure to capture the impact of explicit government support on bank risk (De Nicoló and Loukoianova, 2012). The charter value hypothesis indicates that state-owned banks take fewer risks to protect future rents (Keeley, 1990), while the market discipline hypothesis supports the view that state-owned banks may be more risk-taking since government support decreases the incentive of outside investors to monitor bank risk-taking (Marques et al., 2013).

(d) Macro-level control variables $Y_{t-1}$ : Following Altunbas et al. (2010) or Marques et al. (2013), we include a series of macro-level control variables, such as GDP growth rate, aggregate inflation, housing price growth rate and fiscal surplus to GDP ratio. According to theory, the impact of these variables on bank risk may vary. On the one hand, better macroeconomic conditions can increase banks' risk taking by causing a change of their risk perceptions (López et al., 2011). When GDP growth rate is higher, banks become more optimistic and tolerant to risks, which makes it more likely for them to soften lending standards (Maddaloni and Peydró, 2011), or allocate riskier assets in their portfolios (Delis and Kouretas, 2011). ${ }^{21}$ Similarly, higher inflation (or housing price) can also lead to higher bank risk through the distortion of banks’ risk preference.

On the other hand, better macroeconomic conditions help to reduce the overall risk of banks by increasing the profit of projects in terms of expected net present value (Kashyap et al., 1993). A boost in inflation and housing prices will increase the collateral value and reduce overall credit risk (Altunbas et al., 2010). Fiscal surplus to GDP ratio is introduced here to reflect the implicit guarantee of governments. ${ }^{22}$ Just like in the case of explicit support of governments, both the charter value hypothesis and the market discipline hypothesis show an

\footnotetext{
${ }^{21}$ This positive relationship has got much attention especially after the crisis of 2008 as more and more scholars try to explore the impact of the change of risk perception and tolerance on bank's risk-taking.

${ }^{22}$ See "The Third Report Related to the Development of Chinese Shadow Banking---A Research on Urban Development Investment Bonds” by Mingdong Liu (2013) from the Institute of World Economics and Politics Chinese Academy of Social Science.
} 
uncertain influence of fiscal surplus to GDP ratio on bank risk. As monetary policy is also identified to be an important determinant of bank risk in China (Zhang and He, 2012), ${ }^{23}$ we include the deposit reserve rate which reflects well the stance of Chinese monetary policy, capturing the risk taking channel of monetary policy. A negative relationship between deposit reserve rate and bank risk is predicted here. To distinguish between national commercial banks and local commercial banks, we control for national macro-level variables and local macro-level variables respectively. To be noted, though GDP growth rate and fiscal surplus to GDP ratio are also used for the construction of promotion index $P_{b, t}$, there is no relevant high multicollinearity problem between promotion index and any one of these two macro-level control variables as low correlation coefficients are evident. ${ }^{24}$

(e) Concentration of banking sector $M_{t-1}$ : We use the Herfindahl-Hirschman index, which is the sum of squared market shares according to bank loans, to measure market concentration of the banking sector. Again, the impact of market concentration on bank risk is ambiguous. Some argue that increasing bank charter values arising from increased market power create incentives for bank managers to act prudently, thereby contributing to lower bank risk (Boot and Greenbaum, 1993; Schaeck et al., 2009; Jiménez et al., 2013). While others such as Boyd and De Nicoló (2005) diverge from this “concentration-stability” view and stress a positive relationship between market concentration and bank risk. They argue that increased market power and higher loan rates may intensify firm's inclination towards riskier investments and thus makes it more likely for banks to experience loan defaults.

(f) Channel-specific variables $B_{b, t}$ : We have four channels in the paper to be tested, i.e. “profitability channel”, “liquidity channel”, "volume channel” and "quality channel”. We basically use return on asset (ROA) as a measure of bank profitability, since ROA can capture the risk related to higher leverage when compared with ROE and it has been regarded as the key ratio for the evaluation of bank profitability (Athanasoglou et al., 2008). Besides, as net interest income constitutes the most important part of Chinese banks, we also proxy bank

\footnotetext{
${ }^{23}$ See the "risk-taking channel” of monetary policy (Delis and Kouretas, 2011; Borio and Zhu, 2012). It can be defined as the impact of changes in policy rates on either risk perceptions or risk-tolerance and hence on the degree of risk in the portfolios, on the pricing of assets, and on the price and non-price terms of the extension of funding (Borio and Zhu, 2012).

${ }^{24}$ The correlation coefficients between promotion index and GDP growth rate and fiscal surplus to GDP ratio are respectively -0.12 and -0.39 .
} 
profitability using an alternative measure: net interest margin. To measure bank liquidity, we use a liquidity ratio which is defined as liquid assets over short-term liabilities to identify the role of bank liquidity in linking promotion and bank risk. Medium and long term loan ratios will also be applied to capture changes in the term structure of bank loans in this process. To measure volume of loans, like Qian et al. (2011), we use the loan to deposit ratio and the growth rate of loans to explore the impact of loan volume in the mechanism. Non-performance loan ratio and loan concentration ratio, which is measured by the loan proportion of the largest individual customer, are proxies of loan quality in the paper.

\subsection{Descriptive Statistics}

$\underline{\text { Table } 3}$ shows descriptive statistics of all the regression variables, based on annual data for the periods 2005-2012. For two key variables, bank risk and promotion, the averages are 3.38 and 3.59 respectively. The promotion index shows a higher variation (around 1.77) than bank risk (around 0.80). To identify whether promotion incentive is one of the significant determinants of bank risk, we still need to go further. Since most Chinese local commercial banks report indicators such as net interest margin, liquidity etc. only after 2006 or 2007, the number of observations for channel-specific variables is lower than for others indicators. Especially the long-term loan ratio has only 294 observations, thus it is important to pay attention to the possible bias related to the lack of observations. Loans still constitute the most important part of bank assets in China, with an average loan to deposit ratio of $63.2 \%$ and an annual growth rate of $25.3 \%$. The high average proportion of outstanding loans of the largest single borrower (23.5\%, greater than the regulatory standard $10 \%$ ) indicates a high loan concentration in the Chinese banking sector. State ownership or state-legal-person ownership are the two most common bank ownership structures accounting for $39 \%$ and $26 \%$, respectively. Moreover, the table also shows ample variation in most channel-specific variables and bank-specific control variables. For example, the minimum liquidity ratio of the sample is only $9.7 \%$, less than half the regulatory standard (25\%), while the maximum liquidity ratio reaches $129.4 \%$. The great variation may be an indication of relatively high volatility or heterogeneity of the Chinese banking sector during this period. For macro-specific control variables, both GDP and housing prices have an average annual growth rate of nearly $13 \%$. In these years we observed a negative value for the average fiscal 
surplus to GDP ratio of $-4.0 \%$.

\section{Empirical Results and Analysis: The Effect of Political Promotion on Bank Risk}

The regression results of our basic specification using both national and local commercial data are presented in Table 4. Columns (1)-(5) report fixed-effect estimation results of the one-period lagged method after controlling for a series of variables, such as industry-specific, bank-specific and macro-specific variables. ${ }^{25}$ Column (6) reports regression results using fiscal decentralization as the instrumental variable for political promotion. As shown in this table, a higher promotion incentive significantly increases bank risk, and the result is robust to all variations across regressions. Specifically, the estimated coefficient of the IV-approach is even larger in absolute value terms than that of the one-period lagged approach: An increase in the promotion index by 1 leads to a decrease in the z-score by 0.072 percent, compared to 0.050 percent in the one-period lagged method.

The remaining coefficients of control variables in Table 4 are largely consistent with our expectations. Greater market concentration is associated with higher bank risk, indicating that higher market power and loan rates resulting from higher concentration may intensify a firm's inclination for riskier investments and thus lead to higher bank risk. Larger and well-capitalized banks show lower risk, which may indicate better risk management by these banks. State owned banks take less risk than banks with other ownership structures, showing that the charter value effect dominates the market discipline effect for the state owned banks. GDP growth rate is positively related to bank risk, indicating that banks tend to soften lending standards or allocate riskier assets in portfolios due to the distortion of their risk preference in better macroeconomic conditions. ${ }^{26}$ Higher inflation is associated with an increased bank risk, which may be due to a change of their risk perception and tolerance as well. The significantly positive coefficient on the deposit reserve rate shows the existence of a risk taking channel of monetary policy in China.

As the effect of political promotion on bank risk may vary with bank types and time, we extend our analysis by testing the differences related to bank types and time. Table 5 gives

\footnotetext{
${ }^{25}$ Since banking sector concentration is highly correlated with deposit reserve rate, thus we haven't included these two variables in the same regression.

${ }^{26}$ This result is also consistent with the research of Xu and Chen (2012) and Zhang and He (2012), who focus on Chinese banks' risk.
} 
regression results using the instrumental variable approach while Tables B2-B5 in Appendix B give results using the one-period lagged approach. For national banks (Column 1), no significantly negative relationship is found between promotion incentive and bank risk, while for local banks (Column 2), higher promotion incentive leads to more bank risk. This result is robust to different estimation approaches and the change of control variables. The difference may be due to the fact that larger number of platforms and closer government-bank relationships make it more likely for banks at prefecture-level and county-level (local banks) to be affected by local politicians' (own) promotion incentives. Column 3 and 4 shows how the relationship between promotion incentive and bank risk differs for two different periods: 2005-2007 and 2008-2012. ${ }^{27}$ As shown in the table, no significant relationship is found before the crisis of 2008, while the relationship has become much more pronounced after the crisis unfolded. An impressive surge in the size of government financing vehicles and the enthusiasm of local politicians for better economic indexes and ranking results to prove their ability of dealing with crises may account for the significantly positive effect of promotion on bank risk.

Table 5 and Tables B2-B5 also allow us to distinguish between the differences of the effects of other control variables on bank risk for different bank types or periods. Banking sector concentration displays a negative impact on the risk of local banks while that impact on the risk of national banks is positive ${ }^{28}$. This indicates that the charter value channel of sector concentration dominates for Chinese local banks. Capital to asset ratio display a significant and robust negative effect only on the risk of local banks, which indicates that local banks with higher capital to asset ratio are placed better to buffer their lending activity against shocks. The reasons for the above differences between national and local banks are historical. In China, national banks, especially large commercial banks, have been under the parachute of the central government ever since the day they were established. A lot of problems such as soft budget constraint, lack of appropriate incentive mechanisms for loan monitoring lead to

\footnotetext{
27 The development of financing platforms shows a big difference between the years 2005-2007 and 2008-2012. But China did not experience a significant difference in economic development due to the global financial crises.

${ }^{28}$ For regression (1) in Table B3, the coefficient of banking sector concentration is negative. This may be due to the serious endogeneity problem in this regression since the number of explanatory variables is limited. The coefficients of banking sector concentration in regression (2) and (4) may be more convincing. Besides, when we use a different model for local banks (see Table 9), positive coefficients can also be found, which further supports a negative relationship between banking sector concentration and bank risk.
} 
the differences in risk taking and management behavior between national and local banks.

Besides the differences for different bank types, we also find remarkable changes over time. Banking sector concentration shows a highly significant and robust positive effect after the crisis, which shows that firm's inclination for riskier investments increase after the crisis and makes it more likely for banks to go bankrupt as banks' market power increases. The growth rate of housing prices is positively related to bank risk before the crisis while this relationship turns to negative after the crisis, indicating that a higher housing price growth rate tends to lead to an increase in the collateral value and thus reduces overall credit risk after the crisis. The impact of GDP growth rate on bank risk also differs in the periods 2005-2007 and 2008-2012. For the latter period, higher GDP growth rate is associated with higher bank risk, which may be attributed to the softening of bank lending standards and increasingly holding riskier assets when banks became optimistic and more tolerant to risks. Before the 2008 crisis, however, the impact of the GDP growth rate is insignificant and even positive.

\section{Further Results and Robustness Check}

\subsection{Testing Mechanisms by which Bank Risk Is Affected}

Thus far, our empirical results have confirmed the prediction of Hypothesis 1, 2, 3: Stronger promotion incentives of local politicians may lead to more bank risk, and this relationship is especially pronounced for local banks and the years after the crisis of 2008. However, we are still mute about the mechanisms through which political promotion affects banks’ risk.

According to the analysis of Hypothesis 1, stronger promotion incentives of local politicians may increase bank risk through the following four channels. The first one is the "liquidity channel”. As shown in Figure 1, 92.1\% of local government debts are spent on public infrastructure projects which indicates that most of the funds borrowed from banks are long-term loans. Besides, the fairly long fund recovery time for these infrastructure projects and problems with debt overdue may also make it more likely for banks to suffer from lower liquidity and thus higher bank risk when promotion incentives are higher. The second channel is the "profitability channel". Similar to the first channel, this channel is also closely associated with local governments' decision how borrowed funds are invested. Low and even negative profits of financing platforms result from low fee collections of infrastructure 
projects; the frequent occurrence of so called "white elephant projects” in China may exert a negative effect on banks' profitability and bank risks. The third channel is related to the bank risk brought about by increasing loan volumes under higher promotion incentives, which can be named as the "volume channel". Besides the infrastructure construction boom, the shorter average tenure of local politicians caused by higher political promotion incentives is another factor that leads to the increase in loan volume. Politicians expect that the debt burden from today will be transferred to their successors after a successful political promotion, strengthening the tendency for local governments to over-issue debts. The fourth channel is the "quality channel". Higher political promotion incentives may stimulate the fast development of financing platforms. Serious problems such as "land finance", bad asset quality, poor debt solvency and imperfect withdrawal mechanism of these unsoundly regulated vehicles are all posing threats to the quality of bank loans, which may result in higher bank risk. Thus, we hypothesize that:

Hypothesis 4. Stronger promotion incentives of local politicians may increase bank risk through the "liquidity channel", the "profitability channel", the "volume channel" the and “quality channel”.

To identify the significant channel through which promotion incentives of local politicians affect banks' risk, we carry out a two-step analysis according to Mackinnon (2008)'s method: ${ }^{29}$ In the first step, we analyze how promotion incentives impact variables like banks' profitability and lending characteristics and how bank risk responds to these variables by estimating the following models:

$$
\begin{gathered}
B_{b, t}=\beta_{0}+\beta_{1} P_{b, t-1}+\beta_{2} X_{b, t-1}+\beta_{3} Y_{t-1}+\beta_{t} M_{t-1}+\varepsilon_{b, t} \\
Z_{b, t}=\gamma_{0}+\gamma_{1} B_{b, t-1}+\gamma_{2} X_{b, t-1}+\gamma_{3} Y_{t-1}+\gamma_{4} M_{t-1}+\vartheta_{b, t}
\end{gathered}
$$

where $B_{b, t}$ represents channel-specific variables, including bank profitability, bank liquidity, volume of loans, and quality of loans, for bank $b$ in period $t . \varepsilon_{b, t}$ and $\vartheta_{b, t}$ are the error terms.

In the second step, we regress the bank risk variable on both the promotion variable $P_{b, t}$

\footnotetext{
${ }^{29}$ See the book called “Introduction to Statistical Mediation Analysis” (Mackinnon, 2008) for more information related to this method.
} 
and the channel-specific variable $B_{b, t}$, i.e.

$$
Z_{b, t}=\delta_{0}+\delta_{1} P_{b, t-1}+\delta_{2} B_{b, t-1}+\delta_{3} X_{b, t-1}+\delta_{4} Y_{t-1}+\delta_{5} M_{t-1}+\vartheta_{b, t}
$$

A certain channel exists when the following two conditions are satisfied: (a) Both $\beta_{1}$ and $\gamma_{1}$ are significant; (b) the inclusion of $B_{b, t}$ in the basic regression (1) will decrease the significance of the impact of local promotion on bank risk, namely $\delta_{1}$ is less significant than $\alpha_{1}$.

Since different measures may reflect different aspects of a certain mediator variable, we use two alternative measures to proxy each channel-specific variable. Table 6-7 show us how promotion incentives impact channel-specific variables like banks' profitability etc., and how bank risk responds to the channel-specific variables. ${ }^{30}$ We find that a higher promotion incentive is significantly related to a lower liquidity ratio, ${ }^{31}$ which provides the evidence that political promotion can affect banks' liquidity in the process of financial resource grabbing. Profitability doesn't depend on promotion incentives, as reflected in the insignificant coefficients for both return on asset and net interest margin. ${ }^{32}$ This may be due to the development of the Chinese shadow banking system and the increasing diversification of bank income in recent years ${ }^{33}$ so that the low profitability of infrastructure projects can hardly exert significant impact on the overall profitability of banks. ${ }^{34}$ Growth rate of loans and loan to deposit ratio depend positively on promotion incentives, showing that larger loan volume occurs under a higher promotion incentive. Non-performance loan ratios and loan concentration ratios also increase with higher promotion incentive, implying a negative relationship between political promotion and loan quality.

for the effect of channel-specific variables on bank risk, the liquidity ratio is negatively

\footnotetext{
${ }^{30}$ Since the impact of promotion incentive on bank risk is not significant for national commercial banks, we only use the sample of local commercial banks in this section to identify the mechanism.

${ }^{31}$ Since we only have 294 observations of medium and long term loan ratios, we cannot exclude the possibility that the insignificant relationship between this ratio and bank risk may be distorted.

${ }^{32}$ The sign of these two measures are totally different. One probable reason is that return on asset also considers non-interest income.

${ }_{33}$ See the report by Mingkang Liu, the former chairman of the China Banking Regulatory Commission in Lujiazui Forum of 2011(http://finance.qq.com/a/20110520/002070.htm).

${ }^{34}$ One may argue that it may take more time until profitability deteriorates. To make sure that this is the reason, we use a 2-5 year lagged promotion index as an explanatory variable of banks' profitability, showing that the coefficients are still insignificant. Thus, if this argument holds, then it will take more time for political promotion to have an impact on banks' profitability
} 
related to bank risk, which is consistent with the findings in literature related to the determinants of bank risk (Laeven and Levine, 2009; Marques, 2013). Higher return on asset is associated with higher bank risk, consistent with the work of Xu and Chen (2012). ${ }^{35}$ Loan volume displays a positive relationship with bank risk, and this result is robust for different control variables and measures. Higher non-performing loan ratios and loan concentration ratios are also identified to be significant determinants of higher bank risk. Based on Table 6-7, we find that profitability is not a significant variable linking promotion incentive and bank risk. Liquidity, ${ }^{36}$ volume and quality of loans significantly depend on promotion incentives and have effects on bank risk as well. However, to confirm whether a certain channel exists, we need to go further by including the corresponding channel-specific variable in our basic regression and compare the significance of the coefficients on promotion incentives in Table 8 with those without channel-specific variables (Table 5 and Table B3). As shown in Table 8, except the growth rate of loans, the effects of promotion on bank risk becomes less significant or even insignificant after the inclusion of those channel-specific variables, showing that bank liquidity (measured by liquidity ratio), loan volume (measured by the loan to deposit ratio) and quality (measured by the non-performing loan ratio and loan concentration) are important variables linking promotion incentive and bank risk. It is to be noted that the volume channel works mainly through the change of loan to deposit ratio rather than the growth rate of loans.

\subsection{The Influence from a Change in Promotion Incentive on a Change of Bank Risk}

Different from our main empirical model, here we examine the relations of interest by comparing changes directly: Does a change in promotion incentives affect the change of bank risk? To answer this question, we further estimate the following difference model:

$$
\Delta Z_{b, t}=\tilde{\alpha}_{0}+\tilde{\alpha}_{1} \Delta P_{b, t-1}+\tilde{\alpha}_{2} \Delta X_{b, t-1}+\tilde{\alpha}_{3} \Delta Y_{t-1}+\tilde{\alpha}_{4} \Delta M_{t-1}+\tilde{\mu}_{b, t}
$$

Where $\Delta Z_{b, t}$ is the change of $z$-score (in logarithm) for bank b. $\Delta P_{b, t-1}$ is the change of

\footnotetext{
${ }^{35}$ We must pay attention to the positive relationship between return on asset and bank risk, since return on asset itself is also an important variable for the construction of the z-score. Ceteris paribus, return on asset is positively related to the z-sore, indicating a negative relationship between return on asset and bank risk. Here, our regressions show that higher return on asset can be associated with higher bank risk, which could be explained by the following reason: From its construction it is clear that z-score equals the return on assets plus the capital asset ratio of each bank divided by the standard deviation of asset returns, which indicates that the z-score is not only related to the level of asset returns, but also related to the volatility of asset returns during the whole rolling windows.

${ }^{36}$ We cannot tell if long-term loan ratio plays a mediating role due to the limited amount of data.
} 
promotion incentives corresponding to bank b. $\Delta X_{b, t-1}$ is the change of bank-level control variables, $\Delta Y_{t-1}$ represents the change of macro-level control variables, $\Delta M_{t-1}$ controls for the change of banking sector's concentration. ${ }^{37}$

Since the impact of political promotion on bank risk is not of importance to national banks, we mainly use local bank data for the analysis in the remaining part of the paper. Table 9 reports the estimation results for the above model. As shown in the table, an increase in the promotion index by 1 leads to a decrease in the relative change of z-score by 0.079 percent, indicating that a variation in the change of promotion incentives can cause the change of bank risk to move in the same direction. Our basic regression model presented in equation (1) may be affected by spurious regression problems which can hardly be detected by econometric tests such as unit root test etc. as our panel data only includes 8 years of observations. The significantly negative coefficient of $\Delta P_{b, t-1}$, consistent with our basic regression, not only tells us how a change in promotion incentives affects the change of bank risk, but also supports our basic regression by showing a low probability for the basic regression to be affected by spurious regression.

\subsection{The Influence of Politicians' Characteristics on the Relationship between Promotion Incentives and Bank Risk}

To further identify the effect of promotion incentives on bank risk, we also check how local politicians' characteristics may affect the impact of promotion incentives on bank risk. Therefore, we incorporate several interaction terms between politicians' characteristics and promotion incentives into our basic regression model (1):

$$
Z_{b, t}=\alpha_{0}+\alpha_{1} P_{b, t-1}+\sum_{j=1}^{4} C_{b, t-1}^{j} * P_{b, t-1}+\alpha_{2} X_{b, t-1}+\alpha_{3} Y_{t-1}+\alpha_{4} M_{t-1}+\mu_{b, t}
$$

Here $C_{b, t-1}^{j}(j=1,2,3,4)$ represents the $j$-th characteristics of politicians (mayors) of the region where local bank $b$ operates in. We consider four characteristics: (1) gender of politicians (=1, female; $=0$, male), (2) nationality of politicians ( $=1$, member of the minority; $=0$, otherwise), (3) working experience of politicians ( $=1$, has worked in an enterprise before;

\footnotetext{
${ }^{37}$ To give an intuitive economic explanation for all the coefficients in our regression, we take differences of the original data (without taking logarithms of some variables which are shown in Table 3.)
} 
=0, otherwise), (4) tenure of politicians, namely how long has a politician been in a certain political position. ${ }^{38}$ We have not included the politicians' age in the model, since high correlation (0.984) exists between the interaction term for age (i.e., age*promotion incentive index) and the promotion incentive index.

$\underline{\text { Table } 10}$ shows the estimation results for the above regression model. As shown in the table, politician characteristics such as gender and nationality have no significant effect on the relationship between promotion incentives and bank risk, indicating that the impact of political promotion incentive on bank risk doesn't depend on the nationality of a politician or if a politician is male or female. Working in an enterprise before may help to decrease the bank risk which is caused by higher political promotion incentives, but the effect is not robust. Tenure has a significant and robust effect on the relationship between promotion incentives and bank risk: the influence of promotion incentives on bank risk is higher for politicians who have a shorter tenure, indicating that politicians who have been appointed to new positions may have more enthusiasm to show their competence in economic development, thus more likely to cause a higher bank risk. ${ }^{39}$

\subsection{Robustness Tests}

We perform four kinds of robustness tests: ${ }^{40}$ we modify (1) the bank risk measure, (2) the political promotion index, (3) the measure of fiscal decentralization, (4) the sample banks and (5) non-linear relationship between promotion index and bank risk.

First, since the results in our paper may depend on the measurement of bank risk, we carry out our analysis again using alternative measures such as the NPL ratio (See Table B6) and the z-score of 3-year and 5-year rolling windows. Though expected default frequency and volatility of equity returns are also commonly found in the literature (Laeven and Levine, 2009; Altunbas et al., 2010), they are inadequate for capturing the risk of most banks, especially that of local banks in China because of the shortage of default and equity return data (Zhang and He, 2012). Our main results still hold when using the alternative measures.

The second robustness check is related to our measure of the political promotion index. In

\footnotetext{
${ }^{38}$ Only a low correlation exists between any two of these interaction terms and between any of these interaction terms and the promotion incentive index.

39 The results also hold when the main variables, as in Section 5.2, are taken in differences.

${ }^{40}$ We only report part of the regression results (Table B6-B9) since there is a large number of regressions here with qualitatively similar results.
} 
the main analysis above, we only use the GDP growth rate, fiscal surplus and employment rate to construct the promotion index since the multiple tasks of a regional government can be effectively converted to a few related tasks. Here, we will show whether our results still hold when we include more indicators in the promotion index. As Li and Zhou (2005) pointed out, local government officials have also been playing an active role in building local infrastructure and attracting foreign investment. Thus, to explicitly reflect political promotion pressure in attracting foreign direct investment and building infrastructure, we add foreign direct investment to the GDP ratio, total freight traffic and per capita area of paved roads in the promotion index (See Table B7) ${ }^{41}$ The empirical results support our hypotheses. Besides, our results still hold when we standardize the economic performance-based promotion index or just use the GDP growth rate, the most important evaluation indicator in the index construction, to proxy promotion incentives. Lastly, we introduce dummy variables related to each value of promotion index ${ }^{42}$, instead of directly use this "linear" index. Results show that the dummy variables which indicate higher promotion index values are associated with higher bank risk (see Table B8).

To exclude the possibility that our instrumental variable approach depends on the measure of fiscal decentralization, we use two other commonly used proxies, the share of local government's spending in total government spending and the share of local government's revenue in total government revenue (See Table B9 and B10). Our IV regression results are very robust in measuring fiscal decentralization.

Furthermore, since some city commercial banks such as Beijing Bank, Nanjing Bank, Jiangsu Bank or Huishang Bank, have been restructured to be provincial banks or listed in the stock exchange, we eliminate these banks to exclude the possibility that they might drive our results. As the effect of political promotion on bank risk is insignificant before 2008, we test the mechanism again using only the sample during 2008-2012. Our main findings still hold after changing the sample.

Lastly, we check if a non-linear regression model can better fit our data. We introduced

\footnotetext{
41 The reason for us to use total freight traffic and per capita area of paved roads to reflect infrastructure building is that about $61.6 \%$ of government debts are spent on transportation and municipal constructions (National Audit Office, 2011) and almost every region reports these indicators in the sample years.

${ }^{42}$ For a promotion index which varies between [0,3n] where $n$ is the number of indicators used for the construction of the index, we introduce 3 n dummy variables.
} 
the quadratic term of promotion index into the model. High correlation exists between this quadratic term and promotion index (0.96), making that a non-linear model with the quadratic term is faced with serious multicollinearity problem. Moreover, likelihood ratio test shows that introducing this quadratic form hasn't help much in enhancing the fitness of our model. ${ }^{43}$

\section{Conclusions}

This paper examines whether political promotion incentives of local politicians provide an explanation for increasing bank risk in China today. Some stylized facts highlight the possibility that political promotion incentives of local government officials may affect bank risk in the process of financial resource grabbing. To this end, we construct an economic performance-based promotion index. Empirical results show that higher promotion incentives significantly increase bank risk and this relationship is even stronger, remarkably stronger for local commercial banks and the years after the crisis of 2008. These results hold in IV-regressions and are robust to a number of modifications, including the change of samples, the way we measure risk and promotion incentives.

Moreover, we test the mechanisms through which political promotion mechanisms can significantly affect bank risk. Among the four possible mechanisms derived from the literature, we find no evidence for a profitability channel, which may be due to the increasing diversification of bank income in recent years (Loechel and Li, 2012). In contrast, bank liquidity, loan volume and loan quality all function as significant mediator variables: Higher political promotion tends to increase bank risk significantly by causing lower bank liquidity, larger volume and lower quality of bank loans.

The results of our analysis have several potential implications for policymakers: First, controlling bank risk may no longer be limited to financial regulation organizations. Policy makers should also pay attention to root causes of an increased bank risks that are to be found in the area of politics. Second, diversifying the way local governments' finance investments can also be one possible risk controlling method. Nowadays local governments which are not legally vested the right to debt raising fill large funding gaps in disguised forms through financing platforms, making it more likely to increase bank risks in the process of financial resource grabbing. Thus, suggesting other financing alternatives such as allowing local

\footnotetext{
43 The p-value of likelihood ratio test is 0.27 .
} 
governments to issue debt securities may help control bank risk by introducing stricter market discipline into government financing. Third, paying close attention to the changes in some bank risk indicators, such as in the bank liquidity ratio, non-performing loan ratio and loan concentration ratio etc. can also help to control the risks caused by political promotion.

\section{References}

Akai, N., and M. Sakata, 2002. "Fiscal Decentralization Contributes to Economic Growth: Evidence from State-Level Cross-Section Data for the United States" Journal of Urban Economics 52, 93-108.

Alesina, A., and G. Tabellini, 1990. "A Positive Theory of Fiscal Deficits and Government Debt” Review of Economic Studies 57, 403-414.

Altunbas, Y. L. Gambacorta, and D. Marques-Ibanez, 2010. "Bank Risk and Monetary Policy” Journal of Financial Stability 6(3), 121-129.

Athanasoglou, P. P., S. N. Brissimis, and M. D. Delis, 2008. "Bank-Specific, Industry-Specific, and Macroeconomic Determinants of Bank Profitability" Journal of International Financial Markets, Institutions and Money 18(2), 121-136.

Beck, T., O. D. Jonghe, and G. Schepens, 2013. "Bank Competition and Stability: Cross-Country Heterogeneity” Journal of Financial Intermediation 22(2), 218-244.

Becker, B., 2007. “Geographical Segmentation of US Capital Markets” Journal of Financial Economics 85, 51-178.

Blanchard, O., and A. Shleifer, 2000. "Federalism with and without Political Centralization: China versus Russia” Technical Report, National Bureau of Economic Research.

Boot, A., and S. Greenbaum, 1993. "Bank Regulation, Reputation and Rents: Theory and Policy Implications” In: Mayer, C. and X. Vives (eds.) Capital Markets and Financial Intermediation. Cambridge: University Press.

Borio, C., and H. Zhu, 2012. "Capital Regulation, Risk-Taking and Monetary Policy: A Missing Link in the Transmission Mechanism?” Journal of Financial Stability 8(4), 236-251.

Boyd J.H., and G. De Nicoló, 2005. "The Theory of Bank Risk-Taking and Competition Revisited” Journal of Finance 60(3), 1329-1343.

Boyd, J. H., and G. D. Runkle, 1993. "Size and Performance of Banking Firms: Testing the Predictions of Theory” Journal of Monetary Economics 31(1), 47-67.

Campbell, J., and G. Taksler, 2003. “Equity Volatility and Corporate Bond Yields” Journal of Finance 58(6), 2321-2350.

Cukierman, A., 2011. "Reflections on the Crisis and on Its Lessons for Regulatory Reform and for Central Bank Policies” Journal of Financial Stability 7, 26-37.

De Nicoló, G., and E. Loukoianova, 2012. "Bank Bailouts and Moral Hazard: Evidence from Germany” Review of Financial Studies 25(8), 2343-2380.

Delis, M. D., and G. P. Kouretas, 2011. "Interest Rates and Bank Risk-taking” Journal of Banking and Finance 35(4),840-855.

Dell’ Aricca, G., L. Laeven, and R. Marquez, 2010. "Monetary Policy, Leverage and Bank 
Risk-Taking” IMF Working Paper, WPS 276.

Dinc, I. S., 2005. "Politicians and Banks: Political Influences on Government-owned Banks in Emerging Markets” Journal of Financial Economics 77, 453-479.

Distinguin, I., T. Kouassi, and A. Tarazi, 2013. "Interbank Deposit and Market Discipline: Evidence from Central and Eastern Europe” Journal of Comparative Economics 41(2), 544-560.

Ebel, R. D., and S. Yilmaz, 2002. "On the Measurement and Impact of Fiscal Decentralization” World Bank, Policy Research Working Paper, No. 2809.

Gambacorta L., and Mistrulli P. E., 2004. "Does Bank Capital Affect Lending Behavior?” Journal of Financial Intermediation 13(4), 436-457.

Gropp, H., H. Hakenes, and I. Schnabel, 2011. "Competition, Risk-Shifting, and Public Bailout Policies” Review of Financial Studies 24(6): 2084-2120.

Gur, N., 2012. "Government Ownership of Banks, Job Creation Opportunities and Employment Growth” Economics Letters 117, 509-512.

Hainz, C., and H. Hakenes, 2012. "The Politician and His Banker - How to Efficiently Grant State Aid” Journal of Public Economics 96, 218-225.

Hakenes, H., and I. Schnabel, 2014. "Bank Bonuses and Bailouts” Journal of Money, Credit and Banking 46, 259-288.

Iannotta, G., G. Nocera, and A. Sironi, 2012. “The Impact of Government Ownership on Bank Risk” Journal of Financial Intermediation 22, 152-176.

Imai, M., 2012. "Local Economic Effects of a Government-owned Depository Institution: Evidence from a Natural Experiment in Japan” Journal of Financial Intermediation 21, $1-22$.

Jiménez, G., J. A. Lopez, and J. Saurina, 2013. "How Does Competition Impact Bank Risk-Taking?” Journal of Financial Stability 9(2), 185-195.

Jin, H., Y. Qian, and B. Weingast, 2005. "Regional Decentralization and Fiscal Incentives: Federalism, Chinese Style” Journal of Public Economics 89,1719-1742.

Kashyap, A. K., J. C. Stein, and D. W. Wilcox, 1993. "Monetary Policy and Credit Conditions: Evidence from the Composition of External Finance” American Economic Review 90(3), 407-428.

Keeley, M. C., 1990. "Deposit Insurance, Risk and Market Power in Banking” American Economic Review 80(5), 1183-1200.

Krueger, A. O., 1974. "The Political Economy of the Rent-seeking Society” American Economic Review 64, 291-303.

La Porta, R., F. Lopez-de-Silanes, and A. Shleifer, 2002. “Government Ownership of Banks” Journal of Finance 57, 265-301.

Laeven, L., and R. Levine, 2009. “Bank Governance, Regulation and Risk Taking” Journal of Financial Economics 93(2), 259-275.

Li, W. A., and X. H. Qian, 2012. "Local Offical Governance and Credit Supply of the City Commercial Banks” China Economic Quarterly(China) 11(4), 1239-1260.

Li, H., and L. Zhou, 2005. "Political Turnover and Economic Performance: The Incentive Role of Personnel Control in China” Journal of Public Economics 89, 1743-1762.

Loechel, H., and H. X. Li, 2012. “China’s Changing Business Model of Banking” EU-China BMT Working Paper Series, No. 010. 
López, M., F. Tenjo, and H. Zárate, 2011. “The Risk-Taking Channel and Monetary Transmission Mechanism in Colombia” prepared for the 2nd BIS CCA Conference on "Monetary Policy, Financial Stability and the Business Cycle”.

Maddaloni, A., and J. L. Peydró, 2011. "Bank Risk-Taking, Securitization, Supervision, and Low Interest Rates: Evidence from Euro-Area and US Lending Standards” Review of Financial Studies 24(6), 2121-2165.

Mackinnon, D. P., 2008. "Introduction to Statistical Mediation Analysis" New York: Routledge.

Marques, L. B., R. Correa, and H. Sapriza, 2013. "International Evidence on Government Support and Risk Taking in the Banking Sector” IMF Working Paper, WP/13/94.

Maskin, E., Y. Qian, and C. Xu, 2000. "Incentives, Information, and Organizational Form” Review of Economic Studies 67(2), 359-378.

Micco, A., U. Panizza, and M. Yanez, 2007. "Bank Ownership and Performance: Do Politics Matter?” Journal of Banking and Finance 31, 219-241.

Pereira, C. M., and L. F. Maia-Filho, 2013. "Brazilian Retail Banking and the 2008 Financial Crisis: Were the Government-Controlled Banks that Important?” Journal of Banking and Finance 37, 2210-2215.

Persson, M., and L. Svensson, 1989. "Why A Stubborn Conservative Would Run A Deficit: Policy with Time-inconsistency Preferences” Quarterly Journal of Economics 104, 325-345.

Persson, T., and G. Tabellini, 2000. "Political Economics: Explaining Economic Policy" Cambridge, Mass: MIT Press.

Qian, X. H., T. Q. Cao, and W. A. Li, 2011. “ Promotion Pressure, Officials' Tenure and Lending Behavior of the City Commercial Banks” Economic Research Journal(China) 12, 72-85.

Qian, J., P. E. Strahan, and Z. Yang, 2015. "The Impact of Incentives and Communication Costs on Information Production and Use: Evidence from Bank Lending” Journal of Finance, Forthcoming.

Qiao, B., J. Martinez-Vazquez, and Y. Xu, 2008. "The Tradeoff between Growth and Equity in Decentralization Policy: China's Experience” Journal of Development Economics 86(1), 112-128.

Sapienza, P., 2004. “The Effect of Government Ownership on Bank Lending” Journal of Financial Economics 72, 357-384.

Schaeck, K., M. Cihak, and S. Wolfe. “Are Competitive Banking Systems More Stable?” Journal of Money, Credit and Banking 41(4), 711-734.

Shleifer, A., and R. W. Vishny, 1994. "Politicians and Firms" Quarterly Journal of Economics 109 (4), 995-1025.

Wang, Y., 2013. "Fiscal Decentralization, Endogenous Policies, and Foreign Direct Investment: Theory and Evidence from China and India” Journal of Development Economics 103, 107-123.

World Bank, 2009, "The Urban Development Investment Corporations (UDICs) in Chongqing, China” World Bank and Chongqing Held Seminar on Urban Development Investment Corporations (UDICs) and Urban Infrastructure Investment and Financing.

Xu, C., 2011. “The Fundamental Institutions of China’s Reform and Development” Journal of 
Economic Literature 49(4), 1076-1151.

Xu, M. D., and X. B. Chen, 2012. "Monetary Policy, Capital Adequacy Ratio and Bank Risk-Taking” Journal of Financial Research(China) 7, 48-62.

Zhang, X. L., and D. X. He, 2012. "Monetary Policy Stance and Bank Risk-Taking: An Empirical Study of Banking Industry in China(2000-2010)” Economic Research Journal(China) 5, 31-44.

Zhou, L. A., 2007. “An Analysis of Promotion Tournament Model” Economic Research Journal(China) 7, 36-50. 
Table 1 Debt Raising Units and Debt Sources of Local Government Debts by the End of 2012

\begin{tabular}{|c|c|c|c|}
\hline \multicolumn{2}{|c|}{ Debt raising units of local government debts } & \multicolumn{2}{|c|}{ Debt sources of local government debts } \\
\hline Debt raising units & Ratio & Debt sources & Ratio \\
\hline Financing platform companies & $45.67 \%$ & Bank loans & $78.07 \%$ \\
\hline $\begin{array}{l}\text { Local governmental departments } \\
\text { and institutions }\end{array}$ & $25.37 \%$ & Bond issuing & $12.06 \%$ \\
\hline Other units & $28.96 \%$ & Other sources & $9.87 \%$ \\
\hline Total & $100 \%$ & Total & $100 \%$ \\
\hline
\end{tabular}

Table 2 Distribution of the Sample

\begin{tabular}{lll}
\hline Type of bank & Number of banks in sample & $\begin{array}{l}\text { Percentage of the total number of } \\
\text { banks (\%) }\end{array}$ \\
\hline Large commercial banks & 5 & 3.4 \\
Join-stock commercial banks & 12 & 8.2 \\
City commercial banks & 94 & 63.9 \\
Rural commercial banks and rural & 36 & 24.5 \\
cooperative financial institutions & 147 & 100 \\
Total & & \\
\hline
\end{tabular}


Table 3 Summary Statistics

\begin{tabular}{|c|c|c|c|c|c|c|}
\hline & Variables & $\mathrm{N}$ & Mean & Std.dev. & Minimum & Maximum \\
\hline Key & z-score (in log) & 1051 & 3.38 & 0.80 & 0.33 & 9.35 \\
\hline variables & Promotion & 1051 & 3.59 & 1.77 & 0 & 9 \\
\hline \multirow{10}{*}{$\begin{array}{l}\text { Channel } \\
\text {-specific } \\
\text { variables }\end{array}$} & Liquidity ratio (in \%) & 832 & 52.50 & 16.32 & 9.71 & 129.42 \\
\hline & Medium and long term loan & 294 & 24.41 & 17.05 & 0.23 & 71.01 \\
\hline & ratio (in \%) & & & & & \\
\hline & Return on asset (in \%) & 1023 & 0.96 & 0.49 & 0 & 2.98 \\
\hline & Net interest margin (in \%) & 743 & 2.66 & 2.43 & 0.38 & 21.91 \\
\hline & Growth rate of loans (in \%) & 1012 & 25.27 & 16.90 & -65.03 & 142.96 \\
\hline & Loan to deposit ratio (in \%) & 888 & 63.21 & 9.76 & 20.62 & 91.48 \\
\hline & Non-performance loan ratio & 816 & 2.37 & 2.39 & 0 & 16.01 \\
\hline & (in \%) & & & & & \\
\hline & Loan concentration (in \%) & 819 & 23.49 & 58.77 & 0.12 & 966.5 \\
\hline $\begin{array}{l}\text { Industry } \\
\text { control }\end{array}$ & $\begin{array}{l}\text { Banking sector concentration } \\
\text { (H-H index) }\end{array}$ & 1051 & 0.11 & 0.01 & 0.10 & 0.13 \\
\hline \multirow{4}{*}{$\begin{array}{l}\text { Bank } \\
\text { controls }\end{array}$} & Bank size (in log) & 1051 & 17.54 & 1.88 & 11.34 & 23.59 \\
\hline & State-ownership & 1051 & 0.39 & 0.49 & 0 & 1 \\
\hline & State-legal-person ownership & 1051 & 0.26 & 0.44 & 0 & 1 \\
\hline & Capital to asset ratio (in \%) & 1051 & 6.33 & 2.91 & 0.03 & 38.40 \\
\hline \multirow{5}{*}{$\begin{array}{l}\text { Macro } \\
\text { controls }\end{array}$} & GDP growth rate (in \%) & 1051 & 12.85 & 2.77 & -1.20 & 28.60 \\
\hline & Inflation (in \%) & 1051 & 3.10 & 2.19 & -2.35 & 8.48 \\
\hline & $\begin{array}{l}\text { Growth rate of housing price } \\
\text { (in \%) }\end{array}$ & 1051 & 12.92 & 8.33 & -10.62 & 56.68 \\
\hline & $\begin{array}{l}\text { Fiscal surplus to GDP ratio } \\
\text { (in \%) }\end{array}$ & 1051 & -4.01 & 4.48 & -38.90 & 4.86 \\
\hline & Deposit reserve rate (in \%) & 1051 & 15.13 & 4.28 & 7.50 & 20.83 \\
\hline
\end{tabular}


Table 4 The Impact of Promotion on Bank Risk: National and Local Banks

\begin{tabular}{|c|c|c|c|c|c|c|}
\hline Variables & $\begin{array}{l}\text { Regression } \\
\text { (1) }\end{array}$ & $\begin{array}{l}\text { Regression } \\
\text { (2) }\end{array}$ & $\begin{array}{l}\text { Regression } \\
\text { (3) }\end{array}$ & $\begin{array}{l}\text { Regression } \\
\text { (4) }\end{array}$ & $\begin{array}{l}\text { Regression } \\
\text { (5) }\end{array}$ & $\begin{array}{l}\text { Regression } \\
\text { with IV }\end{array}$ \\
\hline Promotion & $\begin{array}{l}-0.049 * * \\
(0.020)\end{array}$ & $\begin{array}{l}-0.039 * \\
(0.020)\end{array}$ & $\begin{array}{l}-0.048 * * \\
(0.021)\end{array}$ & $\begin{array}{l}-0.056 * * \\
(0.022)\end{array}$ & $\begin{array}{l}-0.050 * * \\
(0.022)\end{array}$ & $\begin{array}{l}-0.072 * \\
(0.044)\end{array}$ \\
\hline $\begin{array}{l}\text { Banking sector } \\
\text { concentration }\end{array}$ & $\begin{array}{l}-11.366^{* * *} \\
(1.620)\end{array}$ & $\begin{array}{l}-8.099 * * * \\
(1.946)\end{array}$ & & $\begin{array}{l}-7.043^{* * *} \\
(2.130)\end{array}$ & --- & --- \\
\hline Bank size & & $\begin{array}{l}0.062^{* * *} \\
(0.020)\end{array}$ & & $\begin{array}{l}0.049 * * \\
(0.024)\end{array}$ & $\begin{array}{l}0.019 \\
(0.024)\end{array}$ & $\begin{array}{l}0.016 \\
(0.025)\end{array}$ \\
\hline State-ownership & & $\begin{array}{l}0.227 \\
(0.147)\end{array}$ & & $\begin{array}{l}0.229 \\
(0.147)\end{array}$ & $\begin{array}{l}0.289 * * \\
(0.144)\end{array}$ & $\begin{array}{l}0.302 * * \\
(0.146)\end{array}$ \\
\hline $\begin{array}{l}\text { State-legal-person } \\
\text { ownership }\end{array}$ & & $\begin{array}{l}0.15667 \\
(0.13429)\end{array}$ & & $\begin{array}{l}0.16312 \\
(0.13421)\end{array}$ & $\begin{array}{l}0.205 \\
(0.133)\end{array}$ & $\begin{array}{l}0.212 \\
(0.133)\end{array}$ \\
\hline Capital to asset ratio & & $\begin{array}{l}0.028^{* * *} \\
(0.010)\end{array}$ & & $\begin{array}{l}0.028^{* * *} \\
(0.010)\end{array}$ & $\begin{array}{l}0.019 * \\
(0.010)\end{array}$ & $\begin{array}{l}0.019 * \\
(0.010)\end{array}$ \\
\hline GDP growth rate & & & $\begin{array}{l}-2.205^{*} \\
(1.193)\end{array}$ & $\begin{array}{l}-2.805^{* *} \\
(1.225)\end{array}$ & $\begin{array}{l}-1.855 \\
(1.232)\end{array}$ & $\begin{array}{l}-2.248 \\
(1.399)\end{array}$ \\
\hline Inflation & & & $\begin{array}{l}-0.029 * * \\
(0.012)\end{array}$ & $\begin{array}{l}0.004 \\
(0.011)\end{array}$ & $\begin{array}{l}-0.028^{* *} \\
(0.013)\end{array}$ & $\begin{array}{l}-0.027^{* *} \\
(0.013)\end{array}$ \\
\hline $\begin{array}{l}\text { Growth rate of } \\
\text { housing price }\end{array}$ & & & $\begin{array}{l}-0.100 \\
(0.305)\end{array}$ & $\begin{array}{l}-0.110 \\
(0.308)\end{array}$ & $\begin{array}{l}-0.117 \\
(0.305)\end{array}$ & $\begin{array}{l}-0.109 \\
(0.305)\end{array}$ \\
\hline $\begin{array}{l}\text { Fiscal surplus to } \\
\text { GDP ratio }\end{array}$ & & & $\begin{array}{l}1.559 \\
(1.095)\end{array}$ & $\begin{array}{l}-0.6768 \\
(1.1948)\end{array}$ & $\begin{array}{l}0.898 \\
(1.228)\end{array}$ & $\begin{array}{l}0.586 \\
(1.336)\end{array}$ \\
\hline Deposit reserve rate & & & $\begin{array}{l}0.049 * * * \\
(0.007)\end{array}$ & --- & $\begin{array}{l}0.044^{* * *} \\
(0.008)\end{array}$ & $\begin{array}{l}0.044^{* * *} \\
(0.008)\end{array}$ \\
\hline Observations & 980 & 980 & 980 & 980 & 980 & 980 \\
\hline R-squared & 0.10 & 0.10 & 0.10 & 0.10 & 0.11 & --- \\
\hline
\end{tabular}

Note: Standard errors are in parentheses. * Significant at 0.01 level. ** Significant at 0.05 level. *** Significant at 0.10 level. Since observations of deposit reserve rate and banking sector concentration is highly correlated, we have not included them in the same regression. 
Table 5 The Impact of Promotion on Bank Risk: by Type and Period

\begin{tabular}{|c|c|c|c|c|}
\hline \multirow[b]{2}{*}{ Variables } & \multicolumn{2}{|c|}{ By type (IV regression) } & \multicolumn{2}{|c|}{ By period(IV regression) } \\
\hline & National bank & Local bank & 2005-2007 & 2008-2013 \\
\hline \multirow[t]{2}{*}{ Promotion } & 0.661 & $-0.111 * *$ & -0.092 & $-0.100 * * *$ \\
\hline & $(0.742)$ & $(0.053)$ & $(0.205)$ & $(0.038)$ \\
\hline Banking sector & ---- & ---- & ---- & ---- \\
\hline concentration & & & & \\
\hline \multirow[t]{2}{*}{ Bank size } & -0.278 & 0.125 & 0.063 & $0.066^{* *}$ \\
\hline & $(0.181)$ & $(0.090)$ & $(0.053)$ & $(0.029)$ \\
\hline \multirow[t]{2}{*}{ State-ownership } & 0.166 & 0.072 & $0.715^{*}$ & 0.166 \\
\hline & $(0.617)$ & $(0.196)$ & $(0.423)$ & $(0.177)$ \\
\hline State-legal-person & $0.619 * *$ & 0.283 & 0.333 & 0.211 \\
\hline ownership & $(0.312)$ & $(0.191)$ & $(0.352)$ & $(0.161)$ \\
\hline Capital to asset & -0.038 & $0.040 * * *$ & 0.009 & $0.023^{* *}$ \\
\hline ratio & $(0.024)$ & $(0.011)$ & $(0.034)$ & $(0.012)$ \\
\hline \multirow[t]{2}{*}{ GDP growth rate } & $-10.171 *$ & $-5.890 * * *$ & 2.774 & $-3.006 * *$ \\
\hline & $(6.037)$ & (1.666) & (5.343) & (1.519) \\
\hline \multirow[t]{2}{*}{ Inflation } & $-0.222 * * *$ & 0.013 & -0.040 & -0.014 \\
\hline & $(0.046)$ & $(0.014)$ & $(0.050)$ & $(0.014)$ \\
\hline Growth rate of & $-2.800 * *$ & 0.176 & $-1.486^{* *}$ & $0.860 * *$ \\
\hline housing price & (1.239) & $(0.323)$ & $(0.695)$ & $(0.371)$ \\
\hline Fiscal surplus to & 18.736 & 1.536 & -3.586 & -1.731 \\
\hline GDP ratio & (12.169) & (1.413) & (8.677) & (1.483) \\
\hline Deposit reserve & $0.149 * * *$ & 0.002 & -0.116 & $0.074 * * *$ \\
\hline rate & $(0.030)$ & $(0.015)$ & $(0.114)$ & $(0.014)$ \\
\hline Observations & 131 & 849 & 305 & 675 \\
\hline R-squared & ---- & ---- & ---- & ---- \\
\hline
\end{tabular}

Note: Regression results with one-period lagged approach can be seen in Table B2-B5 in Appendix B. Standard errors are in parentheses. * Significant at 0.01 level. ** Significant at 0.05 level. *** Significant at 0.10 level. 
Table 6 The Impact of Promotion on Channel-Specific Variables

\begin{tabular}{|c|c|c|c|c|c|c|}
\hline $\begin{array}{l}\text { Channel-specific } \\
\text { variables }\end{array}$ & Indicators & $\begin{array}{l}\text { Regression } \\
(1)\end{array}$ & $\begin{array}{l}\text { Regression } \\
(2)\end{array}$ & $\begin{array}{l}\text { Regression } \\
\text { (3) }\end{array}$ & $\begin{array}{l}\text { Regression } \\
\text { (4) }\end{array}$ & $\begin{array}{l}\text { Regression } \\
\text { (5) }\end{array}$ \\
\hline \multirow[t]{4}{*}{ Liquidity } & Liquidity ratio & $-1.190 * *$ & $-1.061^{* *}$ & $-1.088^{* *}$ & $-1.076^{* *}$ & $-1.131^{* *}$ \\
\hline & & $(0.500)$ & $(0.506)$ & $(0.531)$ & $(0.533)$ & $(0.536)$ \\
\hline & Long-term loan & 0.599 & 0.478 & 0.448 & 0.373 & 0.462 \\
\hline & ratio & $(0.441)$ & $(0.448)$ & $(0.474)$ & $(0.485)$ & $(0.485)$ \\
\hline \multirow[t]{4}{*}{ Profitability } & Return on asset & 0.001 & 0.002 & 0.018 & 0.012 & 0.017 \\
\hline & & $(0.011)$ & $(0.011)$ & $(0.012)$ & $(0.012)$ & $(0.012)$ \\
\hline & Net interest & 0.001 & -0.026 & 0.031 & 0.049 & 0.040 \\
\hline & margin & $(0.011)$ & $(0.061)$ & $(0.065)$ & $(0.065)$ & $(0.065)$ \\
\hline \multirow[t]{4}{*}{ Volume } & Loan to deposit & $0.867 * * *$ & $0.579 * *$ & $0.694 * *$ & $0.508^{*}$ & $0.584 * *$ \\
\hline & ratio & $(0.277)$ & $(0.274)$ & $(0.284)$ & $(0.280)$ & $(0.284)$ \\
\hline & Growth rate of & $1.765^{* *}$ & $1.481 * *$ & $1.615^{* *}$ & $1.452 * *$ & $1.469 * *$ \\
\hline & loans & $(0.688)$ & $(0.672)$ & $(0.734)$ & $(0.715)$ & $(0.714)$ \\
\hline \multirow[t]{4}{*}{ Quality } & Non-performing & $0.181^{* * *}$ & $0.179 * * *$ & $0.148 * *$ & $0.134 * *$ & $0.136 * *$ \\
\hline & loan ratio & $(0.066)$ & $(0.066)$ & $(0.070)$ & $(0.068)$ & (0.069) \\
\hline & Loan & $4.113^{* * *}$ & $3.743 * * *$ & $3.559 * *$ & $3.546 * * *$ & $3.256 * *$ \\
\hline & $\begin{array}{l}\text { concentration } \\
\text { ratio }\end{array}$ & (1.314) & (1.301) & (1.397) & (1.365) & (1.378) \\
\hline
\end{tabular}

Note: This part is based on the sample of local commercial banks only, since the impact of promotion incentive on bank risk is not significant for national banks (same for Table 7-9). We only present coefficients of the promotion variable. Control variables of regression (1)-(5) are the same as before. Standard errors are in parentheses. * Significant at 0.01 level. ** Significant at 0.05 level. *** Significant at 0.10 level. 
Table 7 The Impact of Channel-Specific Variables on Bank Risk

\begin{tabular}{|c|c|c|c|c|c|c|}
\hline $\begin{array}{l}\text { Channel-specific } \\
\text { variables }\end{array}$ & Indicators & $\begin{array}{l}\text { Regression } \\
\text { (1) }\end{array}$ & $\begin{array}{l}\text { Regression } \\
\text { (2) }\end{array}$ & $\begin{array}{l}\text { Regression } \\
\text { (3) }\end{array}$ & $\begin{array}{l}\text { Regression } \\
\text { (4) }\end{array}$ & $\begin{array}{l}\text { Regression } \\
\text { (5) }\end{array}$ \\
\hline \multirow[t]{4}{*}{ Liquidity } & Liquidity ratio & $4.113^{* * *}$ & $3.743 * * *$ & $3.559 * *$ & $3.546 * * *$ & $3.256 * *$ \\
\hline & & (1.314) & (1.301) & (1.397) & (1.365) & (1.378) \\
\hline & Long-term loan & 0.010 & $0.012^{* *}$ & 0.008 & $0.010^{*}$ & 0.010 \\
\hline & ratio & $(0.006)$ & $(0.006)$ & $(0.006)$ & $(0.006)$ & $(0.006)$ \\
\hline \multirow[t]{4}{*}{ Profitability } & Return on asset & $-0.192 * * *$ & $-0.224 * * *$ & $-0.273 * * *$ & $-0.221 * * *$ & $-0.270 * * *$ \\
\hline & & $(0.054)$ & $(0.053)$ & $(0.055)$ & $(0.053)$ & $(0.054)$ \\
\hline & Net interest & 0.003 & 0.001 & 0.001 & 0.0004 & -0.0002 \\
\hline & margin & $(0.011)$ & $(0.011)$ & $(0.011)$ & $(0.011)$ & $(0.011)$ \\
\hline \multirow[t]{4}{*}{ Volume } & Loan to deposit & $-0.009 * *$ & $-0.007 *$ & $-0.009 * *$ & $-0.008 * *$ & $-0.008 * *$ \\
\hline & ratio & $(0.004)$ & $(0.004)$ & $(0.004)$ & $(0.004)$ & $(0.004)$ \\
\hline & Growth rate of & $-0.003 * *$ & $-0.003^{* * *}$ & $-0.003 * *$ & $-0.003 * * *$ & $-0.003 * * *$ \\
\hline & loans & $(0.001)$ & $(0.001)$ & $(0.001)$ & $(0.001)$ & $(0.001)$ \\
\hline \multirow[t]{5}{*}{ Quality } & Non-performing & $-0.026 * *$ & $-0.030 * * *$ & $-0.018 *$ & $-0.033^{* * *}$ & $-0.019 *$ \\
\hline & loan ratio & $(0.011)$ & $(0.011)$ & $(0.010)$ & $(0.011)$ & $(0.010)$ \\
\hline & Loan & $-0.001^{* *}$ & $-0.001^{* *}$ & $-0.001 *$ & $-0.001^{* *}$ & $-0.001 *$ \\
\hline & concentration & $(0.000)$ & $(0.000)$ & $(0.000)$ & $(0.000)$ & $(0.000)$ \\
\hline & ratio & & & & & \\
\hline
\end{tabular}

Note: We only present coefficients of mediator variables. Control variables of regression (1)-(5) are the same as before. Standard errors are in parentheses. * Significant at 0.01 level. ** Significant at 0.05 level. *** Significant at 0.10 level. 
Table 8 The Inclusion of Possible Channel-Specific Variables in the Basic Regression

\begin{tabular}{|c|c|c|c|c|c|c|c|c|c|c|}
\hline \multirow[b]{2}{*}{ Variables } & \multicolumn{2}{|c|}{$\begin{array}{l}\text { Liquidity } \\
\text { ratio }\end{array}$} & \multicolumn{2}{|c|}{$\begin{array}{c}\text { Growth rate } \\
\text { of loans }\end{array}$} & \multicolumn{2}{|c|}{$\begin{array}{c}\text { Loan to } \\
\text { deposit ratio }\end{array}$} & \multicolumn{2}{|c|}{$\begin{array}{l}\text { Non-perfor- } \\
\text { mance loan } \\
\text { ratio }\end{array}$} & \multicolumn{2}{|c|}{$\begin{array}{c}\text { Loan } \\
\text { concentrati- } \\
\text { on }\end{array}$} \\
\hline & $\begin{array}{l}\text { Regres- } \\
\text { sion (4) }\end{array}$ & $\begin{array}{l}\text { Regress- } \\
\text { ion(5) }\end{array}$ & $\begin{array}{l}\text { Regress- } \\
\text { ion (4) }\end{array}$ & $\begin{array}{l}\text { Regress- } \\
\text { ion(5) }\end{array}$ & $\begin{array}{l}\text { Regress- } \\
\text { ion (4) }\end{array}$ & $\begin{array}{l}\text { Regress- } \\
\text { ion(5) }\end{array}$ & $\begin{array}{l}\text { Regress- } \\
\text { ion (4) }\end{array}$ & $\begin{array}{l}\text { Regress- } \\
\text { ion(5) }\end{array}$ & $\begin{array}{l}\text { Regress- } \\
\text { ion (4) }\end{array}$ & $\begin{array}{l}\text { Regress- } \\
\text { ion(5) }\end{array}$ \\
\hline Promotion & $\begin{array}{l}-0.020 \\
(0.028)\end{array}$ & $\begin{array}{l}-0.019 \\
(0.028)\end{array}$ & $\begin{array}{l}-0.072 * * * \\
(0.024)\end{array}$ & $\begin{array}{l}-0.076^{* * *} \\
(0.024)\end{array}$ & $\begin{array}{l}-0.045^{*} \\
(0.024)\end{array}$ & $\begin{array}{l}-0.045^{*} \\
(0.023)\end{array}$ & $\begin{array}{l}-0.061^{* *} \\
(0.024)\end{array}$ & $\begin{array}{l}-0.056^{* *} \\
(0.024)\end{array}$ & $\begin{array}{l}-0.042 \\
(0.028)\end{array}$ & $\begin{array}{l}-0.042 \\
(0.028)\end{array}$ \\
\hline $\begin{array}{l}\text { Banking } \\
\text { sector } \\
\text { concentration }\end{array}$ & $\begin{array}{l}0.010 \\
(5.738)\end{array}$ & ---- & $\begin{array}{l}12.195 * \\
* * \\
(3.379)\end{array}$ & --- & $\begin{array}{l}-0.641 \\
(4.702)\end{array}$ & ---- & $\begin{array}{l}1.037 \\
(4.284)\end{array}$ & --- & $\begin{array}{l}9.174 * \\
(5.161)\end{array}$ & --- \\
\hline Bank size & $\begin{array}{l}0.345^{* *} \\
* \\
(0.105)\end{array}$ & $\begin{array}{l}0.142 \\
(0.118)\end{array}$ & $\begin{array}{l}0.365 * * \\
* \\
(0.076)\end{array}$ & $\begin{array}{l}0.189 * * \\
(0.092)\end{array}$ & $\begin{array}{l}0.299 * * \\
* \\
(0.089)\end{array}$ & $\begin{array}{l}0.178 * \\
(0.099)\end{array}$ & $\begin{array}{l}0.278 * * \\
* \\
(0.077)\end{array}$ & $\begin{array}{l}0.028 \\
(0.088)\end{array}$ & $\begin{array}{l}0.580 * * \\
* \\
(0.108)\end{array}$ & $\begin{array}{l}0.400 * * \\
* \\
(0.124)\end{array}$ \\
\hline $\begin{array}{l}\text { State-owners- } \\
\text { hip }\end{array}$ & $\begin{array}{l}-0.235 \\
(0.277)\end{array}$ & $\begin{array}{l}-0.118 \\
(0.276)\end{array}$ & $\begin{array}{l}-0.030 \\
(0.198)\end{array}$ & $\begin{array}{l}0.059 \\
(0.199)\end{array}$ & $\begin{array}{l}-0.075 \\
(0.240)\end{array}$ & $\begin{array}{l}-0.015 \\
(0.238)\end{array}$ & $\begin{array}{l}0.028 \\
(0.195)\end{array}$ & $\begin{array}{l}0.124 \\
(0.192)\end{array}$ & $\begin{array}{l}-0.185 \\
(0.226)\end{array}$ & $\begin{array}{l}-0.087 \\
(0.225)\end{array}$ \\
\hline $\begin{array}{l}\text { State-legal-pe- } \\
\text { rson } \\
\text { ownership }\end{array}$ & $\begin{array}{l}0.390 \\
(0.246)\end{array}$ & $\begin{array}{l}0.433^{*} \\
(0.246)\end{array}$ & $\begin{array}{l}0.302 \\
(0.194)\end{array}$ & $\begin{array}{l}0.305 \\
(0.195)\end{array}$ & $\begin{array}{l}0.395^{*} \\
(0.211)\end{array}$ & $\begin{array}{l}0.422 * * \\
(0.211)\end{array}$ & $\begin{array}{l}0.324^{*} \\
(0.192)\end{array}$ & $\begin{array}{l}0.321^{*} \\
(0.191)\end{array}$ & $\begin{array}{l}0.052 \\
(0.208)\end{array}$ & $\begin{array}{l}0.078 \\
(0.209)\end{array}$ \\
\hline $\begin{array}{l}\text { Capital to } \\
\text { asset ratio }\end{array}$ & $\begin{array}{l}0.031^{* *} \\
(0.015)\end{array}$ & $\begin{array}{l}0.025 \\
(0.015)\end{array}$ & $\begin{array}{l}0.049 * * \\
* \\
(0.011)\end{array}$ & $\begin{array}{l}0.040 * * \\
* \\
(0.012)\end{array}$ & $\begin{array}{l}0.044^{* *} \\
* \\
(0.011)\end{array}$ & $\begin{array}{l}0.041 * * \\
* \\
(0.011)\end{array}$ & $\begin{array}{l}0.045^{* *} \\
* \\
(0.012)\end{array}$ & $\begin{array}{l}0.034 * * \\
* \\
(0.012)\end{array}$ & $\begin{array}{l}0.014 \\
(0.012)\end{array}$ & $\begin{array}{l}0.008 \\
(0.012)\end{array}$ \\
\hline $\begin{array}{l}\text { GDP growth } \\
\text { rate }\end{array}$ & $\begin{array}{l}-2.880 * \\
(1.554)\end{array}$ & $\begin{array}{l}-1.735 \\
(1.603)\end{array}$ & $\begin{array}{l}-6.470 * \\
* * \\
(1.371)\end{array}$ & $\begin{array}{l}-5.613 * \\
* * \\
(1.441)\end{array}$ & $\begin{array}{l}-3.301 * \\
* \\
(1.333)\end{array}$ & $\begin{array}{l}-2.598 * \\
(1.378)\end{array}$ & $\begin{array}{l}-3.320 * \\
* \\
(1.330)\end{array}$ & $\begin{array}{l}-1.331 \\
(1.389)\end{array}$ & $\begin{array}{l}-2.518 * \\
(1.481)\end{array}$ & $\begin{array}{l}-1.701 \\
(1.556)\end{array}$ \\
\hline Inflation & $\begin{array}{l}0.006 \\
(0.012)\end{array}$ & $\begin{array}{l}-0.016 \\
(0.017)\end{array}$ & $\begin{array}{l}0.003 \\
(0.012)\end{array}$ & $\begin{array}{l}0.011 \\
(0.014)\end{array}$ & $\begin{array}{l}0.003 \\
(0.011)\end{array}$ & $\begin{array}{l}-0.012 \\
(0.014)\end{array}$ & $\begin{array}{l}0.011 \\
(0.011)\end{array}$ & $\begin{array}{l}-0.021 \\
(0.015)\end{array}$ & $\begin{array}{l}-0.008 \\
(0.012)\end{array}$ & $\begin{array}{l}-0.009 \\
(0.017)\end{array}$ \\
\hline $\begin{array}{l}\text { Growth rate of } \\
\text { housing price }\end{array}$ & $\begin{array}{l}-0.055 \\
(0.371)\end{array}$ & $\begin{array}{l}-0.059 \\
(0.369)\end{array}$ & $\begin{array}{l}0.024 \\
(0.322)\end{array}$ & $\begin{array}{l}0.064 \\
(0.326)\end{array}$ & $\begin{array}{l}0.019 \\
(0.314)\end{array}$ & $\begin{array}{l}0.016 \\
(0.313)\end{array}$ & $\begin{array}{l}0.124 \\
(0.318)\end{array}$ & $\begin{array}{l}0.142 \\
(0.315)\end{array}$ & $\begin{array}{l}-0.069 \\
(0.339)\end{array}$ & $\begin{array}{l}-0.088 \\
(0.340)\end{array}$ \\
\hline $\begin{array}{l}\text { Fiscal surplus } \\
\text { to GDP ratio }\end{array}$ & $\begin{array}{l}2.317 \\
(1.538)\end{array}$ & $\begin{array}{l}2.419 \\
(1.532)\end{array}$ & $\begin{array}{l}1.754 \\
(1.364)\end{array}$ & $\begin{array}{l}1.802 \\
(1.380)\end{array}$ & $\begin{array}{l}2.154 \\
(1.339)\end{array}$ & $\begin{array}{l}2.235^{*} \\
(1.337)\end{array}$ & $\begin{array}{l}1.488 \\
(1.286)\end{array}$ & $\begin{array}{l}1.881 \\
(1.278)\end{array}$ & $\begin{array}{l}1.369 \\
(2.086)\end{array}$ & $\begin{array}{l}1.406 \\
(2.097)\end{array}$ \\
\hline $\begin{array}{l}\text { Deposit } \\
\text { reserve rate }\end{array}$ & ---- & $\begin{array}{l}0.041^{* *} \\
(0.020)\end{array}$ & ---- & $\begin{array}{l}-0.007 \\
(0.015)\end{array}$ & --- & $\begin{array}{l}0.026 \\
(0.016)\end{array}$ & ---- & $\begin{array}{l}0.055 * * \\
* \\
(0.017)\end{array}$ & ---- & $\begin{array}{l}0.005 \\
(0.020)\end{array}$ \\
\hline Liquidity ratio & $\begin{array}{l}0.005^{* *} \\
(0.002)\end{array}$ & $\begin{array}{l}0.006 * * \\
(0.002)\end{array}$ & & & & & & & & \\
\hline $\begin{array}{l}\text { Growth rate of } \\
\text { loans }\end{array}$ & & & $\begin{array}{l}-0.003 * \\
* * \\
(0.001)\end{array}$ & $\begin{array}{l}-0.003 * \\
* * \\
(0.001)\end{array}$ & & & & & & \\
\hline $\begin{array}{l}\text { Loan to } \\
\text { deposit ratio }\end{array}$ & & & & & $\begin{array}{l}-0.008 * \\
* \\
(0.004)\end{array}$ & $\begin{array}{l}-0.009 * \\
* \\
(0.004)\end{array}$ & & & & \\
\hline $\begin{array}{l}\text { Non-perform- } \\
\text { ance loan ratio }\end{array}$ & & & & & & & $\begin{array}{l}-0.034 * \\
* * \\
(0.011)\end{array}$ & $\begin{array}{l}-0.021 * \\
* \\
(0.010)\end{array}$ & & \\
\hline $\begin{array}{l}\text { Loan } \\
\text { concentration }\end{array}$ & & & & & & & & & $\begin{array}{l}-0.001^{*} \\
* \\
(0.000)\end{array}$ & $\begin{array}{l}-0.001^{*} \\
(0.000)\end{array}$ \\
\hline
\end{tabular}

Note: We only report regressions with the most control variables here, i.e. regression (4) and regression (5). Standard errors are in parentheses. * Significant at 0.01 level. ** Significant at 0.05 level. *** Significant at 0.10 level 
Table 9 How A Change in Promotion Incentives Affects the Change of Bank Risk

\begin{tabular}{|c|c|c|c|c|c|c|}
\hline Variables & $\begin{array}{l}\text { Regression } \\
\text { (1) }\end{array}$ & $\begin{array}{l}\text { Regression } \\
(2)\end{array}$ & $\begin{array}{l}\text { Regression } \\
\text { (3) }\end{array}$ & $\begin{array}{l}\text { Regression } \\
\text { (4) }\end{array}$ & $\begin{array}{l}\text { Regression } \\
\text { (5) }\end{array}$ & $\begin{array}{l}\text { Regression } \\
\text { with IV }\end{array}$ \\
\hline Promotion & $\begin{array}{l}-0.044^{* *} \\
(0.020)\end{array}$ & $\begin{array}{l}-0.042^{* *} \\
(0.020)\end{array}$ & $\begin{array}{l}-0.064 * * * \\
(0.022)\end{array}$ & $\begin{array}{l}-0.060 * * * \\
(0.022)\end{array}$ & $\begin{array}{l}-0.062 * * * \\
(0.022)\end{array}$ & $\begin{array}{l}-0.079 * * \\
(0.036)\end{array}$ \\
\hline $\begin{array}{l}\text { Banking sector } \\
\text { concentration }\end{array}$ & $\begin{array}{l}19.762^{* * *} \\
(5.824)\end{array}$ & $\begin{array}{l}19.088^{* * *} \\
(5.806)\end{array}$ & & $\begin{array}{l}21.538^{* * *} \\
(6.318)\end{array}$ & ---- & --- \\
\hline Bank size & & $\begin{array}{l}0.027 \\
(0.035)\end{array}$ & & $\begin{array}{l}0.027 \\
(0.038)\end{array}$ & $\begin{array}{l}0.033 \\
(0.038)\end{array}$ & $\begin{array}{l}0.029 \\
(0.039)\end{array}$ \\
\hline State-ownership & & $\begin{array}{l}0.538 * * \\
(0.220)\end{array}$ & & $\begin{array}{l}0.537 * * \\
(0.220)\end{array}$ & $\begin{array}{l}0.533 * * \\
(0.223)\end{array}$ & $\begin{array}{l}0.538 * * \\
(0.223)\end{array}$ \\
\hline $\begin{array}{l}\text { State-legal-person } \\
\text { ownership }\end{array}$ & & $\begin{array}{l}0.325 \\
(0.211)\end{array}$ & & $\begin{array}{l}0.324 \\
(0.211)\end{array}$ & $\begin{array}{l}0.307 \\
(0.213)\end{array}$ & $\begin{array}{l}0.312 \\
(0.213)\end{array}$ \\
\hline $\begin{array}{l}\text { Capital to asset } \\
\text { ratio }\end{array}$ & & $\begin{array}{l}0.026^{* *} \\
(0.013)\end{array}$ & & $\begin{array}{l}0.026 * * \\
(0.013)\end{array}$ & $\begin{array}{l}0.027^{* *} \\
(0.013)\end{array}$ & $\begin{array}{l}0.027 * * \\
(0.013)\end{array}$ \\
\hline GDP growth rate & & & $\begin{array}{l}-2.458^{* *} \\
(1.192)\end{array}$ & $\begin{array}{l}-2.218^{*} \\
(1.145)\end{array}$ & $\begin{array}{l}-2.245^{*} \\
(1.203)\end{array}$ & $\begin{array}{l}-2.588 * \\
(1.330)\end{array}$ \\
\hline Inflation & & & $\begin{array}{l}-0.001 \\
(0.016)\end{array}$ & $\begin{array}{l}-0.005 \\
(0.009)\end{array}$ & $\begin{array}{l}-0.001 \\
(0.016)\end{array}$ & $\begin{array}{l}0.001 \\
(0.016)\end{array}$ \\
\hline $\begin{array}{l}\text { Growth rate of } \\
\text { housing price }\end{array}$ & & & $\begin{array}{l}-0.090 \\
(0.233)\end{array}$ & $\begin{array}{l}0.117 \\
(0.230)\end{array}$ & $\begin{array}{l}-0.053 \\
(0.232)\end{array}$ & $\begin{array}{l}-0.034 \\
(0.234)\end{array}$ \\
\hline $\begin{array}{l}\text { Fiscal surplus to } \\
\text { GDP ratio }\end{array}$ & & & $\begin{array}{l}-0.528 \\
(1.221)\end{array}$ & $\begin{array}{l}-0.773 \\
(1.282)\end{array}$ & $\begin{array}{l}-0.967 \\
(1.294)\end{array}$ & $\begin{array}{l}-1.088 \\
(1.310)\end{array}$ \\
\hline Deposit reserve rate & & & $\begin{array}{l}0.006 \\
(0.027)\end{array}$ & --- & $\begin{array}{l}0.007 \\
(0.027)\end{array}$ & $\begin{array}{l}0.004 \\
(0.028)\end{array}$ \\
\hline Observations & 723 & 723 & 723 & 723 & 723 & 723 \\
\hline R-squared & 0.10 & 0.17 & 0.10 & 0.17 & 0.15 & 0.15 \\
\hline
\end{tabular}

Note: All the variables in this table are in difference forms. Standard errors are in parentheses. * Significant at 0.01 level. ** Significant at 0.05 level. *** Significant at 0.10 level 
Table 10 Politicians' Characteristics and the Relationship between Promotion Incentives and Bank Risk

\begin{tabular}{|c|c|c|c|c|c|c|}
\hline Variables & $\begin{array}{l}\text { Regression } \\
\text { (1) }\end{array}$ & $\begin{array}{l}\text { Regression } \\
\text { (2) }\end{array}$ & $\begin{array}{l}\text { Regression } \\
\text { (3) }\end{array}$ & $\begin{array}{l}\text { Regression } \\
\text { (4) }\end{array}$ & $\begin{array}{l}\text { Regression } \\
\text { (5) }\end{array}$ & $\begin{array}{l}\text { Regression } \\
\text { with IV }\end{array}$ \\
\hline Promotion*gender & $\begin{array}{l}-0.028 \\
(0.035)\end{array}$ & $\begin{array}{l}-0.034 \\
(0.034)\end{array}$ & $\begin{array}{l}-0.019 \\
(0.034)\end{array}$ & $\begin{array}{l}-0.022 \\
(0.034)\end{array}$ & $\begin{array}{l}-0.025 \\
(0.034)\end{array}$ & $\begin{array}{l}-0.008 \\
(0.037)\end{array}$ \\
\hline $\begin{array}{l}\text { Promotion*nation- } \\
\text { ality }\end{array}$ & $\begin{array}{l}-0.091 \\
(0.130)\end{array}$ & $\begin{array}{l}-0.123 \\
(0.126)\end{array}$ & $\begin{array}{l}-0.101 \\
(0.128)\end{array}$ & $\begin{array}{l}-0.106 \\
(0.126)\end{array}$ & $\begin{array}{l}-0.117 \\
(0.127)\end{array}$ & $\begin{array}{l}-0.073 \\
(0.133)\end{array}$ \\
\hline $\begin{array}{l}\text { Promotion*working } \\
\text { experience }\end{array}$ & $\begin{array}{l}0.034^{*} \\
(0.020)\end{array}$ & $\begin{array}{l}0.022 \\
(0.020)\end{array}$ & $\begin{array}{l}0.036 * \\
(0.020)\end{array}$ & $\begin{array}{l}0.026 \\
(0.020)\end{array}$ & $\begin{array}{l}0.028 \\
(0.020)\end{array}$ & $\begin{array}{l}0.043 * \\
(0.023)\end{array}$ \\
\hline Promotion*tenure & $\begin{array}{l}0.011^{* *} \\
(0.005)\end{array}$ & $\begin{array}{l}0.011^{* *} \\
(0.005)\end{array}$ & $\begin{array}{l}0.010^{* *} \\
(0.005)\end{array}$ & $\begin{array}{l}0.011^{* *} \\
(0.005)\end{array}$ & $\begin{array}{l}0.010^{* *} \\
(0.005)\end{array}$ & $\begin{array}{l}0.016^{* *} \\
(0.007)\end{array}$ \\
\hline Promotion & $\begin{array}{l}-0.079 * * \\
(0.032)\end{array}$ & $\begin{array}{l}-0.061^{*} \\
(0.031)\end{array}$ & $\begin{array}{l}-0.099 * * * \\
(0.033)\end{array}$ & $\begin{array}{l}-0.092^{* * *} \\
(0.032)\end{array}$ & $\begin{array}{l}-0.094^{* * *} \\
(0.033)\end{array}$ & $\begin{array}{l}-0.182^{* *} \\
(0.078)\end{array}$ \\
\hline $\begin{array}{l}\text { Banking sector } \\
\text { concentration }\end{array}$ & $\begin{array}{l}-7.293 * * * \\
(1.995)\end{array}$ & $\begin{array}{l}11.516^{* * *} \\
(3.680)\end{array}$ & & $\begin{array}{l}13.970^{* * *} \\
(3.768)\end{array}$ & ---- & ---- \\
\hline Bank size & & $\begin{array}{l}0.429 * * * \\
(0.089)\end{array}$ & & $\begin{array}{l}0.417 * * * \\
(0.091)\end{array}$ & $\begin{array}{l}0.233^{* *} \\
(0.107)\end{array}$ & $\begin{array}{l}0.212 * \\
(0.109)\end{array}$ \\
\hline State-ownership & & $\begin{array}{l}-0.137 \\
(0.212)\end{array}$ & & $\begin{array}{l}-0.143 \\
(0.210)\end{array}$ & $\begin{array}{l}-0.041 \\
(0.211)\end{array}$ & $\begin{array}{l}-0.016 \\
(0.214)\end{array}$ \\
\hline $\begin{array}{l}\text { State-legal-person } \\
\text { ownership }\end{array}$ & & $\begin{array}{l}0.202 \\
(0.215)\end{array}$ & & $\begin{array}{l}0.235 \\
(0.214)\end{array}$ & $\begin{array}{l}0.223 \\
(0.216)\end{array}$ & $\begin{array}{l}0.258 \\
(0.219)\end{array}$ \\
\hline $\begin{array}{l}\text { Capital to asset } \\
\text { ratio }\end{array}$ & & $\begin{array}{l}0.052 * * * \\
(0.014)\end{array}$ & & $\begin{array}{l}0.049 * * * \\
(0.014)\end{array}$ & $\begin{array}{l}0.040 * * * \\
(0.014)\end{array}$ & $\begin{array}{l}0.039 * * * \\
(0.014)\end{array}$ \\
\hline GDP growth rate & & & $\begin{array}{l}-4.409 * * \\
(1.721)\end{array}$ & $\begin{array}{l}-5.640 * * * \\
(1.615)\end{array}$ & $\begin{array}{l}-4.874^{* * *} \\
(1.718)\end{array}$ & $\begin{array}{l}-6.219 * * * \\
(2.037)\end{array}$ \\
\hline Inflation & & & $\begin{array}{l}0.007 \\
(0.015)\end{array}$ & $\begin{array}{l}0.015 \\
(0.013)\end{array}$ & $\begin{array}{l}0.026 \\
(0.016)\end{array}$ & $\begin{array}{l}0.031 * \\
(0.017)\end{array}$ \\
\hline $\begin{array}{l}\text { Growth rate of } \\
\text { housing price }\end{array}$ & & & $\begin{array}{l}0.381 \\
(0.381)\end{array}$ & $\begin{array}{l}0.171 \\
(0.376)\end{array}$ & $\begin{array}{l}0.250 \\
(0.380)\end{array}$ & $\begin{array}{l}0.252 \\
(0.383)\end{array}$ \\
\hline $\begin{array}{l}\text { Fiscal surplus to } \\
\text { GDP ratio }\end{array}$ & & & $\begin{array}{l}1.521 \\
(1.681)\end{array}$ & $\begin{array}{l}1.890 \\
(1.653)\end{array}$ & $\begin{array}{l}1.878 \\
(1.680)\end{array}$ & $\begin{array}{l}1.443 \\
(1.726)\end{array}$ \\
\hline Deposit reserve rate & & & $\begin{array}{l}0.030^{* * *} \\
(0.009)\end{array}$ & & $\begin{array}{l}-0.013 \\
(0.017)\end{array}$ & $\begin{array}{l}-0.015 \\
(0.017)\end{array}$ \\
\hline Observations & 673 & 673 & 673 & 673 & 673 & 673 \\
\hline R-squared & 0.05 & 0.12 & 0.10 & 0.14 & 0.12 & 0.11 \\
\hline
\end{tabular}

Note: All the variables in this table are in difference forms. Standard errors are in parentheses. * Significant at 0.01 level. ** Significant at 0.05 level. *** Significant at 0.10 level 


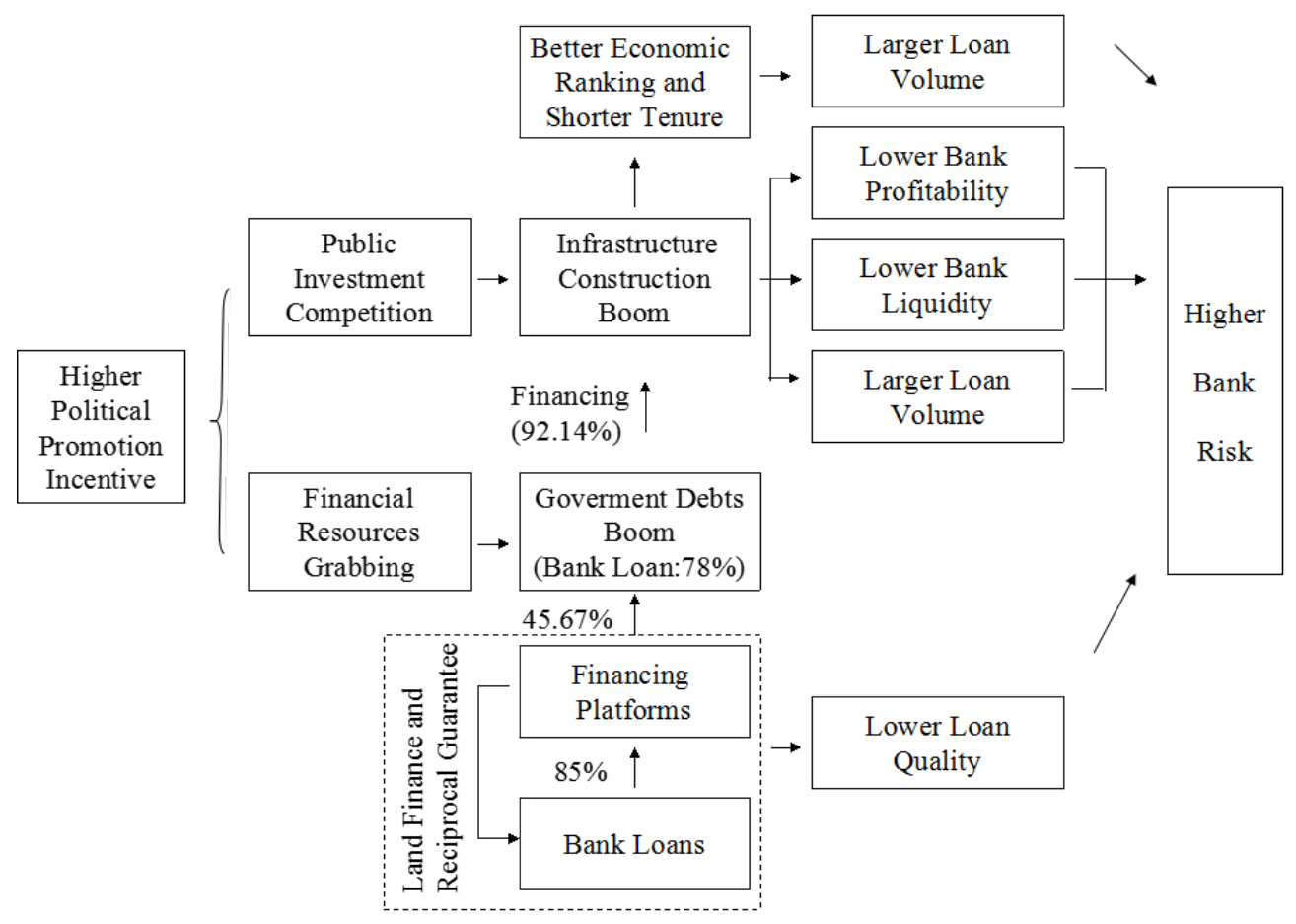

Figure 1 A Promotion-Motivated Competition Model and its Relationship with Bank Risk ${ }^{44}$

44 Data source: The Audit Report by National Audit Office of the People’s Republic of China (No.24 of 2013, http:/ /www.audit.gov.cn/n1992130/n1992150/n1992500/3291665.html). 


\section{Appendix A: Construction of the Promotion incentive $P_{b, t}$}

We follow three steps to construct the Promotion incentive $P_{b, t}$ :

Step one: Construction of the pressure score $S_{i, t}^{k}$

1. Distinguish between two kinds of indicators. The first one are indicators satisfying the condition that a higher value implies better economic performance, and the second one are those satisfying the opposite condition that a higher value implies worse economic performance. Let $e_{i, t}^{k}(k=1,2, \ldots, n)$ be the $k$-th evaluation indicator of local politicians' performance in region $i$ and $S_{i, t}^{k} \in\{0,1,2,3\}$ be the pressure score assigned to region $i$ based on the $k$-th evaluation indicator.

2. For an indicator $e_{i, t}^{k}$ belonging to the first category, if the value of it falls into the interval $\left[V_{\min },\left(\bar{V}+V_{\min }\right) / 2\right)$, where $V_{\min }$ and $\bar{V}$ are the minimum value and average value of the corresponding comparable sample respectively ${ }^{45}$, assign three to $S_{i, t}^{k}$. If the value of $e_{i, t}^{k}$ falls into the interval $\left[\left(\bar{V}+V_{\min }\right) / 2, \bar{V}\right)$, assign two to $S_{i, t}^{k}$. If the value of $e_{i, t}^{k}$ falls into the interval $\left[\bar{V},\left(V_{\max }+\bar{V}\right) / 2\right)$ where $V_{\max }$ is the maximum value of corresponding comparable sample, assign one to $S_{i, t}^{k}$. If the value of $e_{i, t}^{k}$ falls into the interval $\left[\left(V_{\max }+\bar{V}\right) / 2, V_{\max }\right]$, assign zero to $S_{i, t}^{k} \cdot{ }^{46}$ Namely,

$$
S_{i, t}^{k}=\left\{\begin{array}{cccc}
0 & , & \text { if } & e_{i, t}^{k} \in\left[\left(V_{\max }+\bar{V}\right) / 2, V_{\max }\right] \\
1 & , & \text { if } & e_{i, t}^{k} \in\left[\bar{V},\left(V_{\max }+\bar{V}\right) / 2\right) \\
2, & \text { if } & e_{i, t}^{k} \in\left[\left(\bar{V}+V_{\min }\right) / 2, \bar{V}\right) \\
3 & , & \text { if } & e_{i, t}^{k} \in\left[V_{\min },\left(\bar{V}+V_{\min }\right) / 2\right)
\end{array} ;\right.
$$

Similarly, we can assign a value among $0,1,2,3$ to $S_{i, t}^{k}$ when $e_{i, t}^{k}$ belongs to the second category and a higher value of $e_{i, t}^{k}$ is associated with a higher value of $S_{i, t}^{k}$. Namely,

\footnotetext{
45 The indicator of a province will be compared with that of the average level of all the provinces. The indicator of a prefecture-level city will be compared with that of the average level of all the prefecture-level cities in the same province.

${ }^{46}$ All existing literature concerned with political promotion indexes only looks into whether the economic performance of a certain area is better than that of the average level. Actually, the difference between the economic performance of a certain area and the average level is also important for political promotion and this difference can be easily found in many economic reports. Thus, our promotion index also verifies this difference.
} 


$$
S_{i, t}^{k}=\left\{\begin{array}{cccc}
0 & , & \text { if } & e_{i, t}^{k} \in\left[V_{\min },\left(\bar{V}+V_{\min }\right) / 2\right] \\
1 & , & \text { if } & e_{i, t}^{k} \in\left(\left(\bar{V}+V_{\min }\right) / 2, \bar{V}\right] \\
2, & \text { if } & e_{i, t}^{k} \in\left(\bar{V},\left(V_{\max }+\bar{V}\right) / 2\right] \\
3 & , & \text { if } & e_{i, t}^{k} \in\left(\left(V_{\max }+\bar{V}\right) / 2, V_{\max }\right]
\end{array} .\right.
$$

Step two: Construction of the promotion pressure index $P_{i, t}$ from $S_{i, t}^{k}$

Our promotion pressure index $P_{i, t}$ for local politicians in region $i$ is constructed as $P_{i, t}=\sum_{k=1}^{n} S_{i, t}^{k}$, where $P_{i, t} \in[0,3 n]$. A higher value of $P_{i, t}$ indicates higher promotion pressure for local politicians in region $i$.

Step three: Construction of the promotion incentive $P_{b, t}$ from $P_{i, t}$

1. For local commercial banks, such as city commercial banks, rural commercial banks and rural cooperative financial institutions, the promotion incentives $P_{b, t}$ corresponds to the promotion pressure index of the regions where these banks belong to, namely: $P_{b, t}=P_{i, t}$

2. For the national commercial banks, the promotion incentives $P_{b, t}$ correspond to the weighted average level of the promotion pressure index, which is constructed as follows:

$$
P_{b, t}=\sum_{j=1}^{31} \frac{N_{j, b}}{N_{b}} P_{j, t}
$$

where $j$ represents the $j$-th province, $N_{b}$ is the number of the subsidiaries of bank $b$ all over the country, $N_{j, b}$ is the number of the subsidiaries of bank $b$ in province $j$. 


\section{Appendix B: More Tables}

Table B1 Table of Major Events Related to Chinese Local Government Debts since 2008

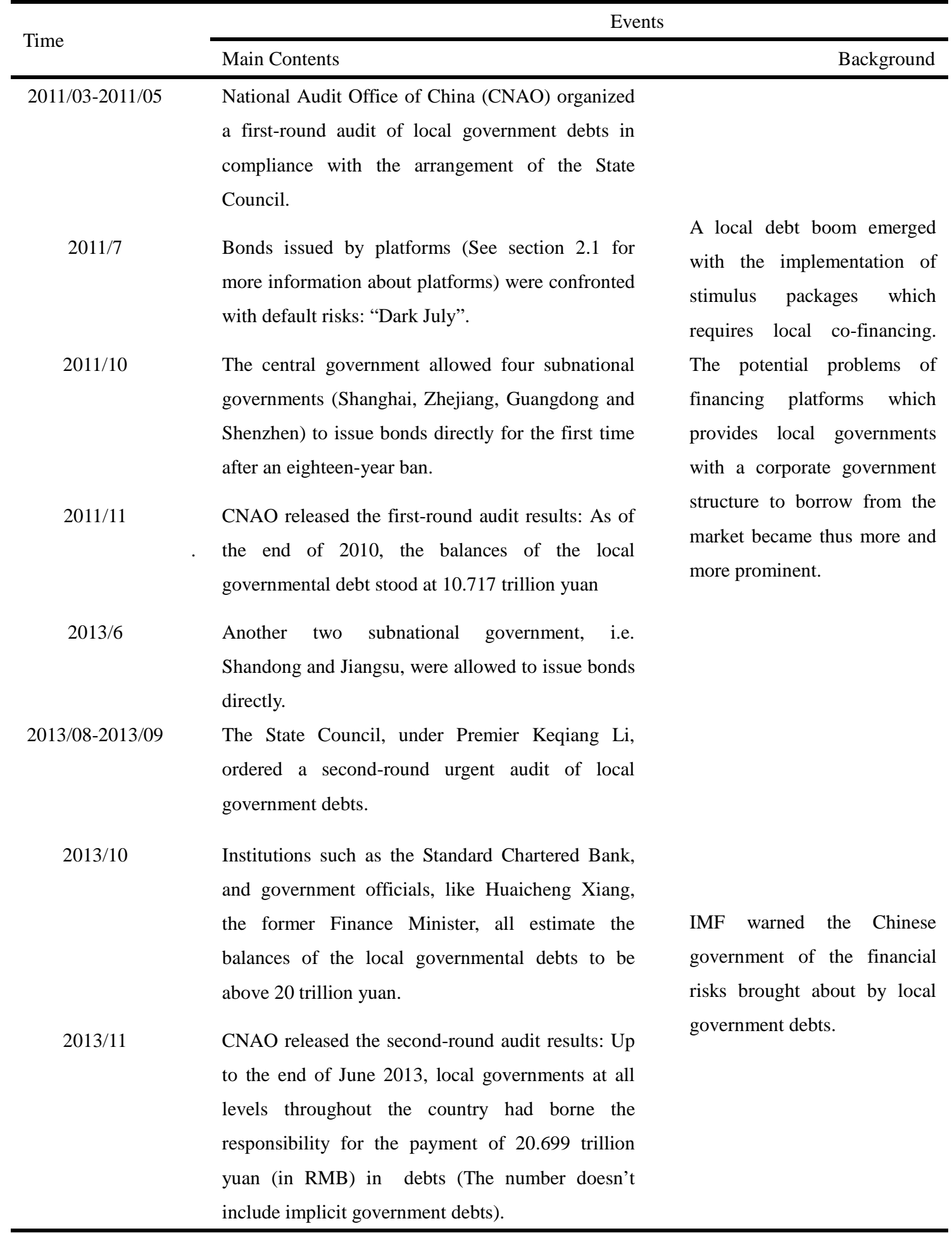

Reference: China Business Journal (http://www.cb.com.cn/economy/2013_1012/1016547.html); 2011 Measures for Experiment on Local Government Unauthorized Bond Issuance (promulgated by the Ministry of Finance, Oct.17, 2011, effective Oct.17, 2011);2013 Measures for Experiment on Local Government Unauthorized Bond Issuance (promulgated by the Ministry of Finance, Jun.25, 2013, effective Jun.25, 2013); Audit Report by National Audit Office of the People's Republic of China (No.35 of 2011 and No.32 of 2013, http://www.audit.gov.cn) 
Table B2 The Impact of Promotion on Bank Risk: National Banks

\begin{tabular}{|c|c|c|c|c|c|}
\hline \multirow[b]{2}{*}{ Variables } & \multicolumn{5}{|c|}{ One-period lagged approach } \\
\hline & Regression (1) & Regression (2) & Regression (3) & Regression (4) & Regression(5) \\
\hline \multirow[t]{2}{*}{ Promotion } & 0.181 & 0.148 & 0.154 & 0.088 & 0.090 \\
\hline & $(0.149)$ & $(0.148)$ & $(0.140)$ & $(0.142)$ & $(0.135)$ \\
\hline Banking sector & $-28.652 * * *$ & $-38.803 * * *$ & & $-39.312 * * *$ & ---- \\
\hline concentration & (3.449) & (5.658) & & $(5.915)$ & \\
\hline \multirow[t]{2}{*}{ Bank size } & & -0.182 & & $-0.312 * *$ & $-0.368 * * *$ \\
\hline & & $(0.116)$ & & $(0.136)$ & $(0.129)$ \\
\hline \multirow[t]{2}{*}{ State-ownership } & & 0.426 & & -0.035 & 0.081 \\
\hline & & $(0.607)$ & & $(0.587)$ & $(0.561)$ \\
\hline State-legal-person & & $0.640 * *$ & & $0.504 *$ & $0.563^{* *}$ \\
\hline ownership & & $(0.304)$ & & $(0.293)$ & $(0.280)$ \\
\hline Capital to asset & & -0.034 & & $-0.040 * *$ & $-0.047 * *$ \\
\hline ratio & & $(0.021)$ & & $(0.020)$ & $(0.019)$ \\
\hline \multirow[t]{2}{*}{ GDP growth rate } & & & -7.570 & $-13.008 * *$ & $-11.316^{* *}$ \\
\hline & & & $(5.508)$ & $(5.700)$ & $(5.412)$ \\
\hline \multirow[t]{2}{*}{ Inflation } & & & $-0.200 * * *$ & -0.036 & $-0.237 * * *$ \\
\hline & & & $(0.039)$ & $(0.040)$ & $(0.039)$ \\
\hline Growth rate of & & & $-2.601 * * *$ & $-1.998 * *$ & $-3.375^{* * *}$ \\
\hline housing price & & & $(0.944)$ & $(0.993)$ & $(0.924)$ \\
\hline Fiscal surplus to & & & 14.013 & -2.074 & 18.279 \\
\hline GDP ratio & & & (11.593) & (11.639) & (11.230) \\
\hline Deposit reserve & & & $0.105^{* * *}$ & ---- & $0.164 * * *$ \\
\hline rate & & & $(0.014)$ & & $(0.021)$ \\
\hline Observations & 131 & 131 & 131 & 131 & 131 \\
\hline R-squared & 0.40 & 0.44 & 0.46 & 0.48 & 0.49 \\
\hline
\end{tabular}

Note: Standard errors are in parentheses. * Significant at 0.01 level. ** Significant at 0.05 level. *** Significant at 0.10 level 
Table B3 The Impact of Promotion on Bank Risk: Local Banks

\begin{tabular}{|c|c|c|c|c|c|}
\hline \multirow[b]{2}{*}{ Variables } & \multicolumn{5}{|c|}{ One-period lagged approach } \\
\hline & Regression (1) & Regression (2) & Regression (3) & Regression (4) & Regression(5) \\
\hline \multirow[t]{2}{*}{ Promotion } & $-0.048^{* *}$ & $-0.039 *$ & $-0.073 * * *$ & $-0.070 * * *$ & $-0.073 * * *$ \\
\hline & $(0.023)$ & $(0.023)$ & $(0.024)$ & $(0.024)$ & $(0.024)$ \\
\hline Banking sector & $-7.480^{* * *}$ & $6.974 * *$ & & $10.105^{* * *}$ & --- \\
\hline concentration & (1.741) & (3.233) & & (3.293) & \\
\hline \multirow[t]{2}{*}{ Bank size } & & $0.306^{* * *}$ & & $0.321^{* * *}$ & 0.133 \\
\hline & & $(0.073)$ & & $(0.075)$ & $(0.089)$ \\
\hline \multirow[t]{2}{*}{ State-ownership } & & -0.020 & & -0.038 & 0.060 \\
\hline & & $(0.197)$ & & $(0.194)$ & $(0.195)$ \\
\hline State-legal-person & & 0.208 & & 0.262 & 0.274 \\
\hline ownership & & $(0.191)$ & & (0.189) & $(0.190)$ \\
\hline Capital to asset & & $0.052 * * *$ & & $0.048 * * *$ & $0.039 * * *$ \\
\hline ratio & & $(0.011)$ & & $(0.011)$ & $(0.011)$ \\
\hline \multirow[t]{2}{*}{ GDP growth rate } & & & $-4.844 * * *$ & $-6.108^{* * *}$ & $-5.160 * * *$ \\
\hline & & & $(1.394)$ & $(1.340)$ & $(1.402)$ \\
\hline \multirow[t]{2}{*}{ Inflation } & & & -0.001 & 0.009 & 0.011 \\
\hline & & & $(0.013)$ & $(0.011)$ & $(0.014)$ \\
\hline Growth rate of & & & 0.236 & 0.100 & 0.145 \\
\hline housing price & & & $(0.321)$ & $(0.318)$ & $(0.320)$ \\
\hline Fiscal surplus to & & & 1.735 & 1.738 & 1.801 \\
\hline GDP ratio & & & $(1.369)$ & $(1.360)$ & $(1.373)$ \\
\hline Deposit reserve & & & $0.030^{* * *}$ & --- & 0.002 \\
\hline rate & & & $(0.007)$ & & $(0.015)$ \\
\hline Observations & 849 & 849 & 849 & 849 & 849 \\
\hline R-squared & 0.03 & 0.10 & 0.10 & 0.11 & 0.10 \\
\hline
\end{tabular}


Table B4 The Impact of Promotion on Bank Risk: 2005-2007

\begin{tabular}{|c|c|c|c|c|c|}
\hline \multirow[b]{2}{*}{ Variables } & \multicolumn{5}{|c|}{ One-period lagged approach } \\
\hline & Regression (1) & Regression (2) & Regression (3) & Regression (4) & Regression(5) \\
\hline \multirow[t]{2}{*}{ Promotion } & -0.028 & -0.056 & -0.011 & -0.020 & -0.039 \\
\hline & $(0.047)$ & $(0.048)$ & $(0.054)$ & $(0.055)$ & $(0.055)$ \\
\hline Banking sector & 3.159 & 2.288 & & $18.905^{* *}$ & ---- \\
\hline concentration & (3.713) & (3.895) & & (8.305) & \\
\hline \multirow[t]{2}{*}{ Bank size } & & 0.023 & & 0.060 & 0.063 \\
\hline & & $(0.038)$ & & $(0.052)$ & $(0.053)$ \\
\hline \multirow[t]{2}{*}{ State-ownership } & & $0.751^{* *}$ & & $0.615^{*}$ & $0.642^{* *}$ \\
\hline & & $(0.319)$ & & $(0.319)$ & $(0.324)$ \\
\hline State-legal-person & & 0.283 & & 0.257 & 0.282 \\
\hline ownership & & $(0.298)$ & & $(0.294)$ & $(0.297)$ \\
\hline Capital to asset & & 0.018 & & 0.001 & 0.007 \\
\hline ratio & & $(0.032)$ & & $(0.032)$ & $(0.033)$ \\
\hline \multirow[t]{2}{*}{ GDP growth rate } & & & 2.949 & 4.101 & 3.933 \\
\hline & & & $(2.937)$ & (3.113) & (3.149) \\
\hline \multirow[t]{2}{*}{ Inflation } & & & -0.047 & $-0.173^{* *}$ & -0.045 \\
\hline & & & $(0.047)$ & $(0.081)$ & $(0.047)$ \\
\hline Growth rate of & & & $-1.619 * *$ & $-1.107^{* *}$ & $-1.496 * *$ \\
\hline housing price & & & $(0.686)$ & $(0.516)$ & $(0.692)$ \\
\hline Fiscal surplus to & & & 1.442 & -0.448 & -1.809 \\
\hline GDP ratio & & & $(4.624)$ & $(5.553)$ & $(5.612)$ \\
\hline Deposit reserve & & & -0.145 & --- & -0.129 \\
\hline rate & & & $(0.100)$ & & $(0.103)$ \\
\hline Observations & 305 & 305 & 305 & 305 & 305 \\
\hline R-squared & 0.01 & 0.04 & 0.04 & 0.10 & 0.10 \\
\hline
\end{tabular}


Table B5 The Impact of Promotion on Bank Risk: 2008-2012

\begin{tabular}{|c|c|c|c|c|c|}
\hline \multirow[b]{2}{*}{ Variables } & \multicolumn{5}{|c|}{ One-period lagged approach } \\
\hline & Regression (1) & Regression (2) & Regression (3) & Regression (4) & Regression(5) \\
\hline \multirow[t]{2}{*}{ Promotion } & $-0.062 * * *$ & $-0.049 * *$ & $-0.075^{* * *}$ & $-0.072 * * *$ & $-0.073^{* * *}$ \\
\hline & $(0.022)$ & $(0.023)$ & $(0.025)$ & $(0.025)$ & $(0.025)$ \\
\hline Banking sector & $-39.739 * * *$ & $-33.451^{* * *}$ & & $-31.420 * * *$ & ---- \\
\hline concentration & $(4.088)$ & (4.535) & & $(5.442)$ & \\
\hline \multirow[t]{2}{*}{ Bank size } & & $0.063^{* * *}$ & & $0.062^{* *}$ & $0.069 * *$ \\
\hline & & $(0.023)$ & & $(0.029)$ & $(0.029)$ \\
\hline \multirow[t]{2}{*}{ State-ownership } & & 0.153 & & 0.161 & 0.151 \\
\hline & & $(0.177)$ & & $(0.176)$ & $(0.177)$ \\
\hline State-legal-person & & 0.216 & & 0.208 & 0.201 \\
\hline ownership & & $(0.160)$ & & $(0.160)$ & $(0.160)$ \\
\hline Capital to asset & & $0.025^{* *}$ & & $0.023^{*}$ & $0.023^{* *}$ \\
\hline ratio & & $(0.011)$ & & $(0.012)$ & $(0.012)$ \\
\hline \multirow[t]{2}{*}{ GDP growth rate } & & & $-3.144 * *$ & $-2.903 * *$ & $-2.491 *$ \\
\hline & & & (1.398) & $(1.392)$ & (1.419) \\
\hline \multirow[t]{2}{*}{ Inflation } & & & $-0.027 * *$ & $0.028^{* *}$ & -0.017 \\
\hline & & & $(0.013)$ & $(0.012)$ & $(0.014)$ \\
\hline Growth rate of & & & $0.798^{* *}$ & $0.800 * *$ & $0.813^{* *}$ \\
\hline housing price & & & $(0.368)$ & $(0.367)$ & $(0.368)$ \\
\hline Fiscal surplus to & & & 0.759 & -0.945 & -1.307 \\
\hline GDP ratio & & & $(1.161)$ & $(1.426)$ & $(1.415)$ \\
\hline Deposit reserve & & & $0.096 * * *$ & ---- & $0.076^{* * *}$ \\
\hline rate & & & $(0.012)$ & & $(0.014)$ \\
\hline Observations & 675 & 675 & 675 & 675 & 675 \\
\hline R-squared & 0.16 & 0.18 & 0.17 & 0.19 & 0.19 \\
\hline
\end{tabular}


Table B6 The Impact of Promotion on Bank Risk: With NPL Ratio as Risk Measure

\begin{tabular}{|c|c|c|c|c|c|}
\hline \multirow[b]{2}{*}{ Variables } & \multirow[b]{2}{*}{ Whole sample } & \multicolumn{2}{|c|}{ By type } & \multicolumn{2}{|c|}{ By period } \\
\hline & & National bank & Local bank & $2005-2007$ & 2008-2012 \\
\hline \multirow[t]{2}{*}{ Promotion } & $0.003 * * *$ & 0.000 & $0.001 * *$ & 0.000 & $0.002 * *$ \\
\hline & $(0.001)$ & $(0.007)$ & $(0.001)$ & $(0.003)$ & $(0.001)$ \\
\hline Banking sector & ---- & ---- & ---- & ---- & ---- \\
\hline concentration & & & & & \\
\hline \multirow[t]{2}{*}{ Bank size } & 0.001 & $0.012 *$ & $0.008 * * *$ & -0.001 & -0.001 \\
\hline & $(0.001)$ & $(0.006)$ & $(0.002)$ & $(0.002)$ & $(0.001)$ \\
\hline \multirow[t]{2}{*}{ State-ownership } & 0.002 & -0.009 & 0.001 & -0.024 & $0.011 * *$ \\
\hline & $(0.005)$ & $(0.027)$ & $(0.005)$ & $(0.029)$ & $(0.004)$ \\
\hline \multirow{2}{*}{$\begin{array}{l}\text { State-legal-person } \\
\text { ownership }\end{array}$} & 0.002 & 0.000 & -0.001 & -0.004 & $0.006^{*}$ \\
\hline & $(0.004)$ & $(0.014)$ & $(0.005)$ & $(0.018)$ & $(0.004)$ \\
\hline \multirow{2}{*}{$\begin{array}{l}\text { Capital to asset } \\
\text { ratio }\end{array}$} & $-0.001^{*}$ & -0.001 & -0.000 & -0.002 & $-0.001 * *$ \\
\hline & $(0.000)$ & $(0.001)$ & $(0.000)$ & $(0.001)$ & $(0.000)$ \\
\hline \multirow[t]{2}{*}{ GDP growth rate } & $-0.199 * * *$ & -0.001 & $-0.135 * * *$ & -0.074 & $-0.089 * *$ \\
\hline & $(0.044)$ & $(0.265)$ & $(0.042)$ & $(0.090)$ & $(0.039)$ \\
\hline \multirow[t]{2}{*}{ Inflation } & $0.004 * * *$ & $0.007 * * *$ & $0.003 * * *$ & 0.007 & $0.002 * * *$ \\
\hline & $(0.000)$ & $(0.002)$ & $(0.000)$ & $(0.004)$ & $(0.000)$ \\
\hline Growth rate of & $0.039 * * *$ & $0.083^{*}$ & $0.015^{*}$ & 0.056 & $0.025^{* * *}$ \\
\hline housing price & (0.011) & $(0.045)$ & $(0.009)$ & $(0.034)$ & $(0.009)$ \\
\hline Fiscal surplus to & $-0.392 * * *$ & -0.686 & 0.101 & $-1.611^{* * *}$ & $-0.265^{* * *}$ \\
\hline GDP ratio & $(0.063)$ & $(0.549)$ & $(0.065)$ & $(0.349)$ & $(0.050)$ \\
\hline Deposit reserve & $-0.003 * * *$ & $-0.005 * * *$ & $-0.004 * * *$ & 0.002 & $-0.002 * * *$ \\
\hline rate & $(0.000)$ & $(0.001)$ & $(0.000)$ & $(0.007)$ & $(0.000)$ \\
\hline Observations & 980 & 131 & 849 & 305 & 675 \\
\hline R-squared & 0.37 & 0.38 & 0.39 & 0.10 & 0.30 \\
\hline
\end{tabular}


Table B7 The Impact of Promotion on Bank Risk: With More Indicators in the Promotion Index

\begin{tabular}{|c|c|c|c|c|c|}
\hline \multirow[b]{2}{*}{ Variables } & \multirow[b]{2}{*}{ Whole sample } & \multicolumn{2}{|c|}{ By type } & \multicolumn{2}{|c|}{ By period } \\
\hline & & National bank & Local bank & $2005-2007$ & 2008-2012 \\
\hline \multirow[t]{2}{*}{ Promotion } & $-0.035 * * *$ & -0.015 & $-0.060 * * *$ & -0.055 & $-0.048 * * *$ \\
\hline & $(0.014)$ & $(0.034)$ & $(0.015)$ & $(0.054)$ & $(0.018)$ \\
\hline Banking sector & ---- & ---- & ---- & ---- & ---- \\
\hline concentration & & & & & \\
\hline \multirow[t]{2}{*}{ Bank size } & 0.005 & $-0.489 * * *$ & 0.043 & $0.133^{* *}$ & 0.047 \\
\hline & $(0.025)$ & $(0.164)$ & $(0.102)$ & $(0.063)$ & $(0.031)$ \\
\hline \multirow[t]{2}{*}{ State-ownership } & $0.347 * *$ & -0.074 & 0.157 & 0.443 & 0.215 \\
\hline & $(0.155)$ & $(0.575)$ & $(0.209)$ & $(0.472)$ & $(0.187)$ \\
\hline \multirow{2}{*}{$\begin{array}{l}\text { State-legal-person } \\
\text { ownership }\end{array}$} & $0.269 *$ & $0.615^{* *}$ & $0.339 *$ & -0.011 & $0.336^{* *}$ \\
\hline & $(0.141)$ & $(0.284)$ & $(0.200)$ & $(0.497)$ & $(0.170)$ \\
\hline \multirow{2}{*}{$\begin{array}{l}\text { Capital to asset } \\
\text { ratio }\end{array}$} & 0.014 & $-0.056 * * *$ & $0.039 * * *$ & 0.019 & $0.026 * *$ \\
\hline & $(0.011)$ & $(0.020)$ & $(0.012)$ & $(0.045)$ & $(0.013)$ \\
\hline \multirow[t]{2}{*}{ GDP growth rate } & -0.982 & $-29.513 * * *$ & $-4.863 * * *$ & $7.782 * *$ & $-2.808 *$ \\
\hline & $(1.271)$ & $(11.028)$ & (1.447) & (3.357) & $(1.488)$ \\
\hline \multirow[t]{2}{*}{ Inflation } & $-0.040 * * *$ & $-0.216^{* * *}$ & -0.003 & 0.003 & -0.018 \\
\hline & $(0.013)$ & $(0.042)$ & $(0.015)$ & $(0.103)$ & $(0.014)$ \\
\hline Growth rate of & -0.122 & $-4.791 * * *$ & 0.158 & -1.411 & $1.061 * *$ \\
\hline housing price & $(0.319)$ & (1.149) & $(0.331)$ & $(0.976)$ & $(0.413)$ \\
\hline Fiscal surplus to & 1.777 & $35.085^{* *}$ & $2.474 *$ & -8.747 & 0.636 \\
\hline GDP ratio & $(1.242)$ & (14.239) & (1.381) & (8.528) & (1.533) \\
\hline Deposit reserve & $0.040 * * *$ & $0.202 * * *$ & 0.004 & 0.069 & $0.098 * * *$ \\
\hline rate & $(0.009)$ & $(0.030)$ & $(0.016)$ & $(0.193)$ & $(0.023)$ \\
\hline Observations & 980 & 131 & 849 & 305 & 675 \\
\hline R-squared & 0.07 & 0.15 & 0.07 & 0.19 & 0.17 \\
\hline
\end{tabular}


Table B8 The Impact of Promotion on Bank Risk: With Dummy Variables to Present Each Value of Promotion Index

\begin{tabular}{|c|c|c|c|c|c|}
\hline \multirow[b]{2}{*}{ Variables } & \multirow[b]{2}{*}{ Whole sample } & \multicolumn{2}{|c|}{ By type } & \multicolumn{2}{|c|}{ By period } \\
\hline & & National bank & Local bank & 2005-2007 & 2008-2012 \\
\hline Promotion & -0.061 & 0.056 & -0.013 & -0.047 & -0.027 \\
\hline _dummy_1 & $(0.079)$ & $(0.350)$ & $(0.082)$ & $(0.186)$ & $(0.096)$ \\
\hline Promotion & $-0.138 *$ & -0.045 & $-0.160 *$ & -0.047 & $-0.185^{*}$ \\
\hline _dummy_2 & $(0.082)$ & $(0.369)$ & $(0.086)$ & $(0.254)$ & $(0.103)$ \\
\hline Promotion & $-0.151 *$ & 0.061 & $-0.251 * * *$ & -0.411 & $-0.206^{*}$ \\
\hline _dummy_3 & $(0.089)$ & $(0.374)$ & $(0.095)$ & $(0.282)$ & $(0.113)$ \\
\hline $\begin{array}{l}\text { Banking sector } \\
\text { concentration }\end{array}$ & ---- & ---- & ---- & ---- & ---- \\
\hline \multirow[t]{2}{*}{ Bank size } & 0.018 & $-0.345^{* *}$ & 0.088 & $-1.181 * * *$ & 0.049 \\
\hline & $(0.024)$ & $(0.138)$ & $(0.088)$ & $(0.423)$ & $(0.115)$ \\
\hline \multirow[t]{2}{*}{ State-ownership } & $0.287 * *$ & 0.049 & 0.127 & 0.032 & 0.018 \\
\hline & $(0.142)$ & $(0.580)$ & $(0.191)$ & $(0.540)$ & $(0.273)$ \\
\hline State-legal-person & 0.196 & $0.572^{*}$ & 0.251 & -0.774 & 0.058 \\
\hline ownership & $(0.130)$ & $(0.312)$ & $(0.186)$ & $(0.739)$ & $(0.255)$ \\
\hline \multirow[t]{2}{*}{ Capital to asset ratio } & 0.013 & $-0.051 * *$ & $0.030 * *$ & 0.061 & $0.030 * *$ \\
\hline & $(0.010)$ & $(0.022)$ & $(0.012)$ & $(0.042)$ & $(0.013)$ \\
\hline \multirow[t]{2}{*}{ GDP growth rate } & -1.657 & $-11.446^{* *}$ & $-5.117 * * *$ & $-10.703 * *$ & $-2.769 *$ \\
\hline & $(1.222)$ & (5.622) & (1.395) & $(4.717)$ & $(1.643)$ \\
\hline \multirow[t]{2}{*}{ Inflation } & $-0.033 * * *$ & $-0.258 * * *$ & 0.006 & 0.013 & -0.009 \\
\hline & $(0.012)$ & $(0.048)$ & $(0.014)$ & $(0.057)$ & $(0.016)$ \\
\hline Growth rate of & -0.181 & $-3.519 * * *$ & 0.159 & -0.248 & $0.820 * *$ \\
\hline housing price & $(0.300)$ & (1.018) & $(0.314)$ & $(0.708)$ & $(0.399)$ \\
\hline Fiscal surplus to & $1.973^{*}$ & $22.164 *$ & $2.508^{*}$ & 7.550 & 0.111 \\
\hline GDP ratio & (1.175) & (13.135) & $(1.334)$ & $(7.922)$ & (1.603) \\
\hline \multirow[t]{2}{*}{ Deposit reserve rate } & $0.046^{* * *}$ & $0.161 * * *$ & 0.012 & 0.200 & $0.069 * * *$ \\
\hline & $(0.008)$ & $(0.025)$ & $(0.015)$ & $(0.139)$ & $(0.025)$ \\
\hline Observations & 980 & 131 & 849 & 305 & 675 \\
\hline R-squared & 0.10 & 0.20 & 0.09 & 0.16 & 0.16 \\
\hline
\end{tabular}

Note: Here we present the case with only GDP indictor which is the most important indicator for political promotion to construct promotion index. Thus promotion index vary between [0,3] and three dummy variables are introduced in this case: Pomotion dummy $i=1$ represents promotion index $=i$ where $i=1,2,3$. Standard errors are in parentheses. * Significant at 0.01 level. ** Significant at 0.05 level. *** Significant at 0.10 level. 
Table B9 The Impact of Promotion on Bank Risk: With the Share of Local Government's Spending in Total Government Spending as IV

\begin{tabular}{|c|c|c|c|c|c|}
\hline \multirow[b]{2}{*}{ Variables } & \multirow[b]{2}{*}{ Whole sample } & \multicolumn{2}{|c|}{ By type } & \multicolumn{2}{|c|}{ By period } \\
\hline & & National bank & Local bank & $2005-2007$ & 2008-2012 \\
\hline \multirow[t]{2}{*}{ Promotion } & $-0.104 * *$ & 0.565 & $-0.073 *$ & -0.094 & $-0.101 *$ \\
\hline & $(0.044)$ & $(2.514)$ & $(0.044)$ & $(0.127)$ & $(0.052)$ \\
\hline Banking sector & ---- & ---- & --- & --- & ---- \\
\hline concentration & & & & & \\
\hline \multirow[t]{2}{*}{ Bank size } & 0.012 & -0.293 & 0.133 & $0.131^{* *}$ & $0.066 * *$ \\
\hline & $(0.025)$ & $(0.421)$ & $(0.090)$ & $(0.064)$ & $(0.029)$ \\
\hline \multirow[t]{2}{*}{ State-ownership } & $0.321 * *$ & 0.151 & 0.060 & 0.497 & 0.167 \\
\hline & $(0.147)$ & $(0.701)$ & $(0.195)$ & $(0.512)$ & $(0.179)$ \\
\hline State-legal-person & $0.221 *$ & 0.609 & 0.274 & 0.016 & 0.212 \\
\hline ownership & $(0.134)$ & $(0.386)$ & $(0.190)$ & $(0.531)$ & $(0.161)$ \\
\hline Capital to asset & $0.019 *$ & -0.039 & $0.039 * * *$ & 0.020 & $0.023 * *$ \\
\hline ratio & $(0.010)$ & $(0.043)$ & $(0.011)$ & $(0.046)$ & $(0.012)$ \\
\hline \multirow[t]{2}{*}{ GDP growth rate } & $-2.795 * *$ & -10.364 & $-5.147 * * *$ & $6.927 *$ & $-3.031 *$ \\
\hline & $(1.402)$ & (7.623) & (1.568) & (3.966) & (1.664) \\
\hline \multirow[t]{2}{*}{ Inflation } & $-0.025 *$ & $-0.225^{* * *}$ & 0.011 & 0.026 & -0.014 \\
\hline & $(0.013)$ & $(0.077)$ & $(0.014)$ & $(0.118)$ & $(0.015)$ \\
\hline Growth rate of & -0.098 & -2.897 & 0.144 & -1.340 & $0.863 * *$ \\
\hline housing price & $(0.306)$ & (2.706) & $(0.321)$ & (1.003) & $(0.377)$ \\
\hline Fiscal surplus to & 0.153 & 18.659 & 1.806 & -10.591 & -1.752 \\
\hline GDP ratio & (1.339) & (12.046) & (1.396) & $(10.212)$ & (1.585) \\
\hline Deposit reserve & $0.043^{* * *}$ & $0.152 * *$ & 0.002 & 0.107 & $0.074^{* * *}$ \\
\hline rate & $(0.008)$ & $(0.067)$ & $(0.015)$ & $(0.210)$ & $(0.014)$ \\
\hline Observations & 980 & 131 & 849 & 305 & 675 \\
\hline R-squared & 0.10 & 0.14 & 0.10 & 0.17 & 0.19 \\
\hline
\end{tabular}


Table B10 The Impact of Promotion on Bank Risk: With the Share of Local Government's Revenue in Total Government Revenue as IV

\begin{tabular}{|c|c|c|c|c|c|}
\hline \multirow[b]{2}{*}{ Variables } & \multirow[b]{2}{*}{ Whole sample } & \multicolumn{2}{|c|}{ By type } & \multicolumn{2}{|c|}{ By period } \\
\hline & & National bank & Local bank & $2005-2007$ & 2008-2012 \\
\hline \multirow[t]{2}{*}{ Promotion } & $-0.134 * * *$ & 0.799 & $-0.076^{*}$ & -0.117 & $-0.111^{*}$ \\
\hline & $(0.051)$ & (1.016) & $(0.039)$ & $(0.132)$ & $(0.057)$ \\
\hline Banking sector & ---- & ---- & ---- & ---- & ---- \\
\hline concentration & & & & & \\
\hline \multirow[t]{2}{*}{ Bank size } & 0.007 & -0.256 & 0.132 & $0.130 * *$ & $0.065 * *$ \\
\hline & $(0.025)$ & $(0.215)$ & $(0.090)$ & $(0.064)$ & $(0.029)$ \\
\hline \multirow[t]{2}{*}{ State-ownership } & $0.339 * *$ & 0.186 & 0.061 & 0.536 & 0.172 \\
\hline & $(0.148)$ & $(0.649)$ & $(0.195)$ & $(0.518)$ & $(0.179)$ \\
\hline State-legal-person & $0.230^{*}$ & $0.632 *$ & 0.274 & 0.056 & 0.216 \\
\hline ownership & $(0.135)$ & $(0.330)$ & $(0.190)$ & $(0.536)$ & $(0.162)$ \\
\hline Capital to asset & $0.019 *$ & -0.036 & $0.039 * * *$ & 0.020 & $0.023^{* *}$ \\
\hline ratio & $(0.010)$ & $(0.027)$ & $(0.011)$ & $(0.046)$ & $(0.012)$ \\
\hline \multirow[t]{2}{*}{ GDP growth rate } & $-3.323 * *$ & -9.894 & $-5.213^{* * *}$ & 6.523 & $-3.224 *$ \\
\hline & $(1.475)$ & (6.411) & $(1.521)$ & $(4.032)$ & $(1.728)$ \\
\hline \multirow[t]{2}{*}{ Inflation } & $-0.023^{*}$ & $-0.219 * * *$ & 0.011 & 0.037 & -0.013 \\
\hline & $(0.013)$ & $(0.051)$ & $(0.014)$ & $(0.120)$ & $(0.015)$ \\
\hline Growth rate of & -0.088 & $-2.662 *$ & 0.147 & -1.304 & $0.881^{* *}$ \\
\hline housing price & $(0.308)$ & (1.449) & $(0.321)$ & (1.009) & $(0.379)$ \\
\hline Fiscal surplus to & -0.265 & 18.846 & 1.782 & -11.714 & -1.910 \\
\hline GDP ratio & (1.390) & (12.653) & (1.389) & (10.403) & (1.631) \\
\hline Deposit reserve & $0.043^{* * *}$ & $0.146^{* * *}$ & 0.002 & 0.122 & $0.073^{* * *}$ \\
\hline rate & $(0.008)$ & $(0.035)$ & $(0.015)$ & $(0.212)$ & $(0.014)$ \\
\hline Observations & 980 & 131 & 849 & 305 & 675 \\
\hline R-squared & 0.10 & 0.16 & 0.10 & 0.17 & 0.19 \\
\hline
\end{tabular}

Note: Standard errors are in parentheses. * Significant at 0.01 level. ** Significant at 0.05 level. *** Significant at 0.10 level 